University of San Diego

Digital USD

Spring 5-22-2021

\title{
Managing Pediatric Atopic Dermatitis in the Allergy Clinic: Use of an Eczema Action Plan to Improve Caregiver Understanding and Self-Efficacy, A Pilot Study
}

Danielle Hubacek

University of San Diego, dhubacek@sandiego.edu

Follow this and additional works at: https://digital.sandiego.edu/dnp

Part of the Allergy and Immunology Commons, Dermatology Commons, Maternal, Child Health and Neonatal Nursing Commons, Pediatric Nursing Commons, and the Skin and Connective Tissue Diseases Commons

\section{Digital USD Citation}

Hubacek, Danielle, "Managing Pediatric Atopic Dermatitis in the Allergy Clinic: Use of an Eczema Action Plan to Improve Caregiver Understanding and Self-Efficacy, A Pilot Study" (2021). Doctor of Nursing Practice Final Manuscripts. 145.

https://digital.sandiego.edu/dnp/145

This Doctor of Nursing Practice Final Manuscript is brought to you for free and open access by the Theses and Dissertations at Digital USD. It has been accepted for inclusion in Doctor of Nursing Practice Final Manuscripts by an authorized administrator of Digital USD. For more information, please contact digital@sandiego.edu. 


\section{UNIVERSITY OF SAN DIEGO \\ Hahn School of Nursing and Health Science \\ DOCTOR OF NURSING PRACTICE}

Managing Pediatric Atopic Dermatitis in the Allergy Clinic: Use of an Eczema Action Plan to Improve Caregiver Understanding and Self-Efficacy, A Pilot Study

by

Danielle H. Hubacek, BSN, RN, DNP Student

A Doctor of Nursing Practice Portfolio presented to the

FACULTY OF THE HAHN SCHOOL OF NURSING AND HEALTH SCIENCE

UNIVERSITY OF SAN DIEGO

In partial fulfillment of the

requirements for the degree

DOCTOR OF NURSING PRACTICE

May 2021

Dr. Sharon B. Kepple, PhD, MSN, FNP-C, PHN (Chickasaw), Faculty Advisor Dr. Sanjeev Jain, MD, PhD, Clinical Mentor 


\section{Table of Contents}

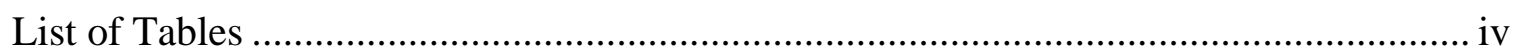

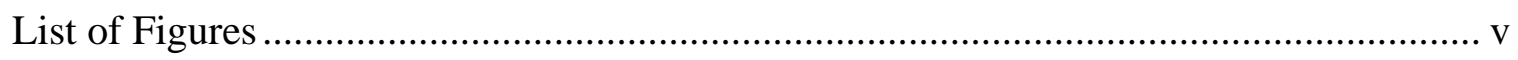

Documentation of Mastery of DNP Program Outcomes .............................................. 1

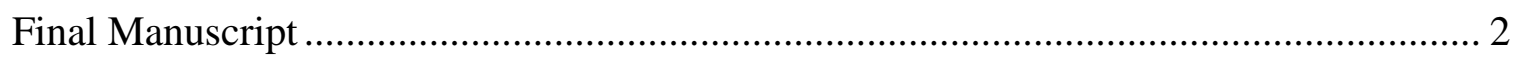

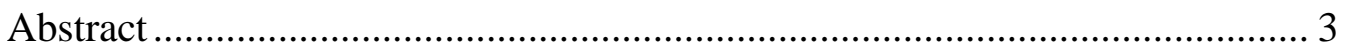

Background and Evidence for Problem .................................................... 5

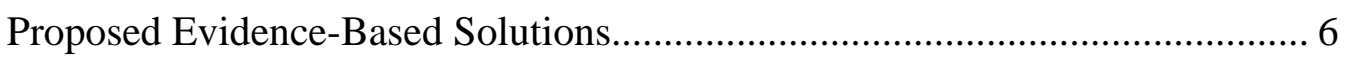

Standardized Education Materials ........................................................ 6

Written Education Materials and Eczema Action Plans .............................. 8

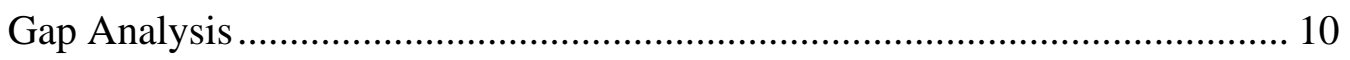

Description of EBP Project ................................................................ 10

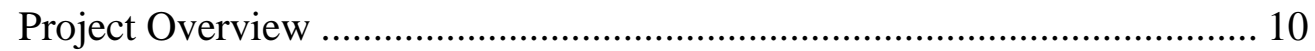

Measurements and Outcomes ............................................................. 12

Anticipated Outcomes..................................................................... 13

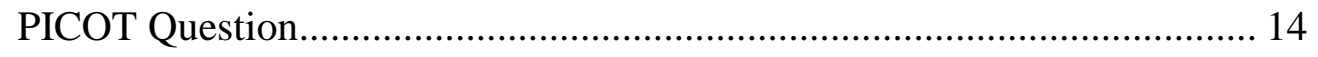

EBP Model ..................................................................................... 14

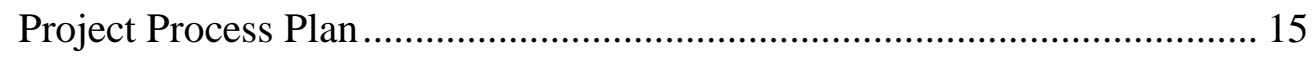

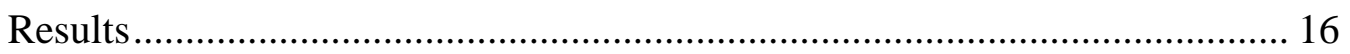

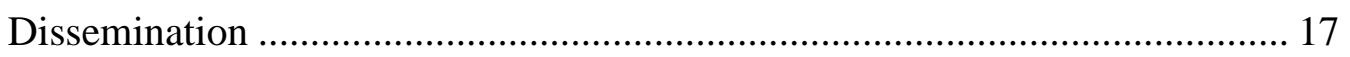

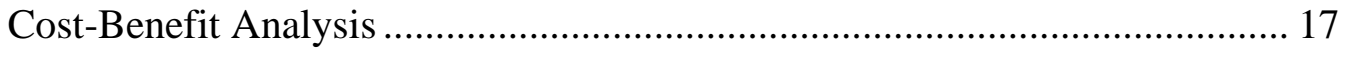

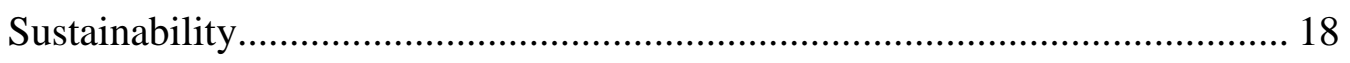

Implications for Clinical Practice ...................................................... 19 


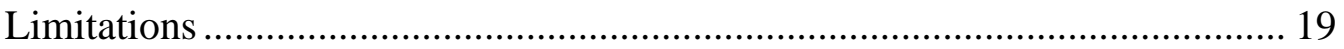

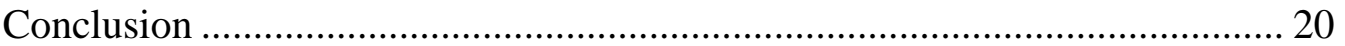

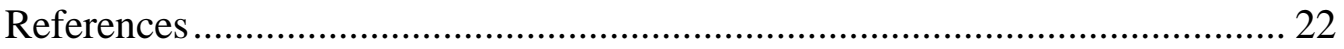

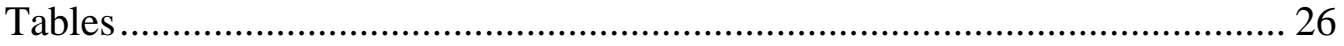

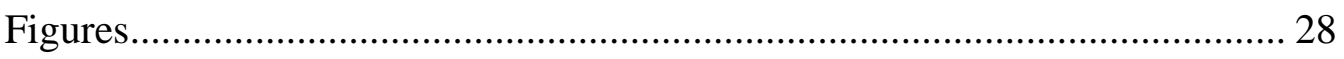

Appendix A Poster Abstract with Letter of Acceptance to Conference .......................... 33

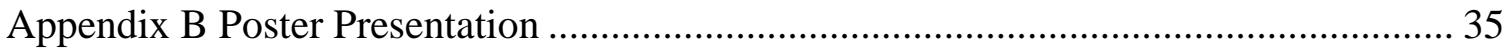

Appendix C PowerPoint Stakeholder Presentation.................................................. 36

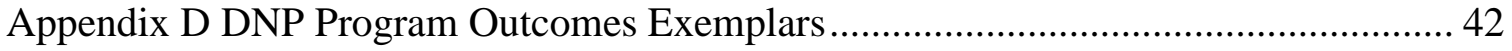

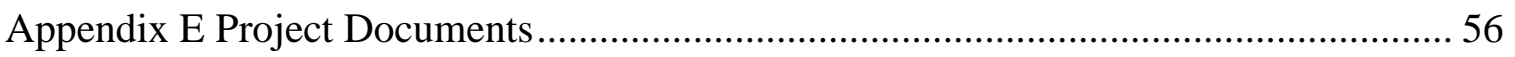

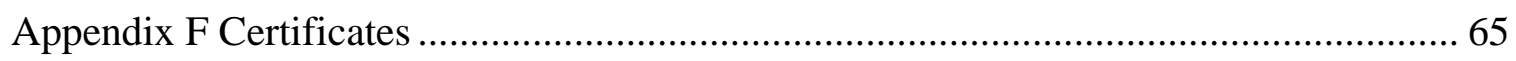




\section{List of Tables}

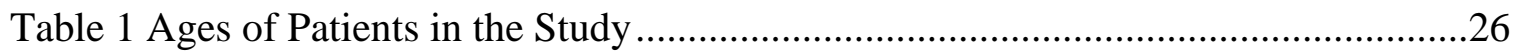

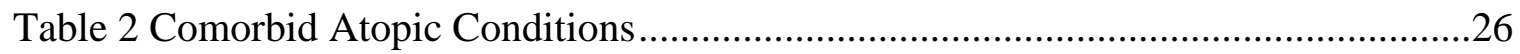

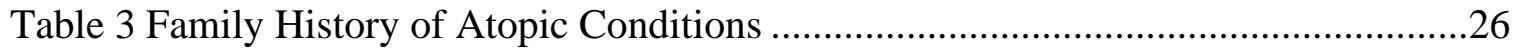

Table 4 Duration of Eczema Diagnosis ................................................................2

Table 5 Previous Use of Eczema Action Plan ..........................................................27

Table 6 Caregiver Understanding of EAP at Initial Visit ...........................................27 


\section{List of Figures}

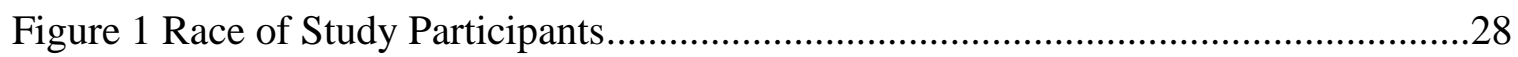

Figure 2 Average POEM Scores Pre/Post EAP ........................................................28

Figure 3 Average PASECI Scores Pre/Post EAP ..................................................29

Figure 4 POEM Score Breakdown Per Question ........................................................30

Figure 5 PASECI Score Breakdown Per Question Pre/Post EAP ..................................31

Figure 6 Caregiver's Comprehension of Eczema Action Plan .....................................32 
Documentation of Mastery of DNP Program Outcomes 


\title{
Final Manuscript
}

Managing Pediatric Atopic Dermatitis in the Allergy Clinic: Use of an Eczema Action Plan to Improve Caregiver Understanding and Self-Efficacy, A Pilot Study

\author{
Danielle Hubacek \\ Dr. Sharon Kepple \\ University of San Diego
}

Hahn School of Nursing and Health Science: Beyster Institute of Nursing Research 


\begin{abstract}
Eczema, or atopic dermatitis, is a complex and chronic condition that affects approximately $10 \%$ of children throughout the United States (Brown et al., 2018). The American Academy of Allergy Asthma \& Immunology (AAAAI) (2017) estimates the average cost of eczema management for each patient is approximately $\$ 3,302$ per year. The complex nature of atopic dermatitis indicates a need for individualized treatment plans. Research has shown that standardized patient teaching, written education materials, and Eczema Action Plans (EAP) reinforce patient teaching, parental understanding, and improve quality of life. This evidence-based practice (EBP) project introduces the use of a written Eczema Action Plan, using the template created by the American Academy of Dermatology (AAD), for patients less than 18 years of age at multiple private allergy clinics in California and Washington. The EAP provides written instruction for how to cleanse and moisturize skin when symptoms are controlled and during a flare, what medications should be used during a mild and moderate flare, and what symptoms should prompt the patient to follow up with their allergist. The implemented clinical intervention included providing an individualized EAP, in addition to standardized written education materials about eczema and its treatment compiled into one handout from the National Institute of Health $(\mathrm{NIH})$ and the AAAAI to the parent or caregiver of the pediatric patient. Patient outcomes were measured using the University of Nottingham's validated Patient Oriented Eczema Measure (POEM) form and parental outcomes were measured using Parental Self-Efficacy Care Index (PAESCI) survey at the introduction of the EAP and again at 6-9-weeks post-intervention. Of the 24 participants enrolled, 20 completed the study. Patient ages ranged from 9 months to 17
\end{abstract}


years. PAESCI scores increased from an average of $47 / 70$ pre-intervention to $60.9 / 70$ post-EAP use, indicating increased caregiver self-efficacy. POEM scores decreased from an average of $8.65 / 28$ pre-EAP to $4.1 / 28$ post-EAP, indicating a reduction in eczema severity. At the time of receiving the EAP, parents had an average understanding of 8.9/10. This increased to an average understanding of a 9.65/10 after using the EAP for 69 weeks, indicating increased understanding after use. Benefits of EAPs along with written education materials include reduction of patient costs on office visits and medications due to flares, improved medication adherence, improved patient and caregiver understanding, and improved patient quality of life. Use of an EAP within an allergy clinic can also allow for better continuity of care between the patient's primary care providers and their allergists.

Keywords: eczema action plan, pediatric atopic dermatitis, allergy, caregiver selfefficacy, POEM, PASECI 
Managing Pediatric Atopic Dermatitis in the Allergy Clinic: Use of an Eczema Action

Plan to Improve Caregiver Understanding and Self-Efficacy

\section{Background and Evidence for Problem}

Eczema, or atopic dermatitis, is a complex and chronic condition that affects approximately $10 \%$ of children throughout the United States (Brown et al., 2018). This is a dynamic, multifactorial condition with periods of acute exacerbations that can vary in severity. The nature of atopic dermatitis requires a treatment plan that is effective in keeping the symptoms at bay and one that can manage acute exacerbations to prevent complications such as infection (Brown et al., 2018). It is recommended by the American Academy of Dermatology (AAD) that atopic dermatitis treatment plans involve skin care regimens, methods for control of itching and inflammation, as well as management of allergic triggers and infection (Brown et al., 2018). There is a high correlation between eczema and other atopic conditions including food and environmental allergies, so it is common for pediatric allergists to manage all atopic conditions presented by the patient. At this time, there is no standardization for treatment of pediatric eczema in the United States, which can lead to inconsistent management of care from the provider and the child's parent or caregiver.

The American Academy of Allergy, Asthma \& Immunology (AAAAI) (2017) estimates the average cost of eczema management for each patient is approximately $\$ 3,302$ per year. These costs can be attributed to visits with a provider in primary care, allergy, or dermatology, eczema-friendly cleansing and skincare products, and prescription medications (AAAAI, 2017). In addition to the high cost of care, the burden of atopic dermatitis has also been found to negatively impact a person's quality of life. 
On average, patients experience a flare for 100 days out of the year (Sauder et al., 2016). Parents of children with eczema often feel unsupported by their providers in treatment of their child's eczema and frequently feel that they are not provided with adequate information to manage the condition at home (Powell et al., 2018). Uncontrolled eczema symptoms of itching, bleeding, pain, and sleep disturbance can lead to limitations of physical activity, social function, and can adversely affect a child's emotional state (Drucker et al., 2017). It is crucial for providers to create a customized and comprehensive treatment plan for a child with atopic dermatitis to achieve a reduction in flares. It is equally as important for those caring for a child with atopic dermatitis to have an adequate understanding of the treatment plan to effectively manage eczema symptoms to mitigate the damaging effect this chronic condition can have on a child's quality of life.

\section{Proposed Evidence-Based Solutions}

A literature review was conducted using key words including eczema action plan, eczema management, atopic dermatitis, atopic dermatitis management, and eczema patient education. CINAHL, PubMed, JSTOR, Cochrane, and Ovid databases were searched. 27 articles were found to be pertinent and reviewed. 17 articles were utilized for the Evidence-Based Practice (EBP) project. Evidence-based solutions proposed by the reviewed articles included use of standardized patient education, written education materials, and written action plans.

\section{Standardized Education Materials}

Standardized education materials for all pediatric patients with atopic dermatitis within a specified clinical setting were shown to be effective for improving quality of life 
and caregiver understanding across several studies. A randomized controlled trial of 134 parents of children with moderate to severe atopic dermatitis measured the change in severity of eczema symptoms using the Scoring Atopic Dermatitis (SCORAD) index and the quality of family life using the Family Dermatology Life Quality Index (FDLQI) after the implementation of a structured short-term parent education program (Pustisek et al., 2016). The education program consisted of written materials that included a corticosteroid use diary and an educational booklet on eczema (Pustisek et al., 2016). The participants also received a lecture that included information presented by dermatologists, psychologists, a dietician and was followed by nurse-led education (Pustisek et al., 2016). The parents in the intervention group reported a significant improvement in the qualityof-life index (Pustisek et al., 2016). While there was no significant improvement in the severity of symptoms for the intervention group, it was noted that the control group sought out additional information on eczema to educate themselves on their child's condition (Pustisek et al., 2016).

A randomized controlled trial of 542 pediatric patients with moderate to severe atopic dermatitis also measured the change in disease severity using the SCORAD index as well as the quality of life with the Children's Dermatology Life Quality index (IDQOL) pre- and post-intervention of four once-weekly group education sessions (Liang et al., 2018). The intervention group showed a significant improvement in eczema severity and understanding of emollient use when compared to the control group (Liang et al., 2018). Additionally, a systematic review of 10 randomized controlled trials reviewing psychological and educational interventions for atopic dermatitis in children revealed an overall increase in quality of life and decrease in symptoms after the 
implementation of nurse-led, multi-disciplinary, or medically led education focused on the child's parent (Ersser et al., 2017). These studies reveal that structured eczema education materials can help to ensure patients receive comprehensive eczema education needed to adequately care for the condition outside of the office.

\section{Written Education Materials and Eczema Action Plans}

Research has shown that another potential evidence-based solution for the deficit in pediatric eczema education is the use of written education materials and more specifically, eczema action plans. A meta-analysis of 287 eczema studies was conducted to provide guidelines for successful treatment of atopic dermatitis (Sidbury et al., 2014). The meta-analysis concluded that written education materials were found to reinforce teaching and recommended their use to prevent and manage disease flares (Sidbury et al., 2014). A randomized controlled trial of 211 caregivers of children with eczema concluded that providers who utilized an eczema care plan documented more comprehensive eczema care than the control group providers (Rea et al., 2018b). Better documentation of a care plan can improve continuity of care, patient understanding, and patient outcomes (Rea et al., 2018b). Rea et al. (2018a) also reported that in a crosssectional analysis of 224 pediatric patients with a diagnosis of eczema, a greater understanding of a child's individualized eczema plan was associated with a higher quality of life. These conclusions were mirrored in a meta-analysis of 388 articles exploring the use of written action plans (WAP) in management of children with atopic dermatitis (Chilsom et al., 2008). Written action plans been proven to be a useful tool in managing other chronic pediatric atopic conditions such as asthma and were proposed to be an ideal choice for management of atopic dermatitis (Chilsom et al., 2008). The goal 
of a written action plan is to provide parents with a step-approach guide to manage their child's chronic condition (Chilsom et al., 2008). The findings concluded the use of WAPs in the care of children with atopic dermatitis has substantial potential for improving both adherence and outcomes (Chilsom et al., 2008).

A randomized controlled trial of 37 pediatric patients measured eczema symptom severity and quality of life using a 10-question survey with a five-point Likert-type scale before and after receiving education with a written Eczema Action Plan (EAP) (Brown et al., 2018). Brown et al. (2018) reported a significant increase in understanding of atopic dermatitis when compared to the control group. In addition, $90 \%$ of the patients who received an EAP felt it was easy to understand and $100 \%$ reported they would like to continue to use this tool (Brown et al., 2018). Similarly, Gilliam et al. (2016) reported that in a randomized controlled trial of 88 pediatric patients, parents of children with atopic dermatitis who received an EAP were more confident managing their child's atopic dermatitis over time as compared with those who did not receive the EAP. Another randomized controlled trial of 44 pediatric patients detected poor patient compliance with eczema treatments and explored the use of an EAP to reduce Eczema Area and Severity Index (EASI) (Sison et al., 2018). Results of the study showed that at four weeks postintervention, statistically significant reductions in EASI scores of the group who received the EAP were present (Sison et al., 2018). Conclusions were drawn that an EAP is a promising tool that can be utilized to improve severity of eczema symptoms and patient compliance with eczema management (Sison et al., 2018). 


\section{Gap Analysis}

The pre-intervention data from eczema education studies show that patients are sent home from office visits without adequate knowledge of atopic dermatitis management resulting in increased eczema symptoms and decreased quality of life. This is in part due to the complex and multifactorial nature of atopic dermatitis, as well as a lack of an all-inclusive approach to managing eczema in children. The post-intervention data from these same studies revealed that the use of structured patient education and written education materials in the form of an individualized Eczema Action Plan were effective in improving caregiver understanding, patient and family quality of life, and reducing eczema symptom severity. In January 2020, the selected private allergy clinic saw 43 patients with a diagnosis of L20.9 (Atopic Dermatitis) at their Fremont location, 27 of which were patients less than 18 years old. All of these patients received the standard eczema education of verbal instructions presented to the child's caregiver. This

patient analysis showed that there was an adequate sample size to justify implementation of an evidence-based practice (EBP) intervention for eczema patient education to incorporate individualized written education materials. The overarching goals of this project were to reduce severity of patient's atopic dermatitis symptoms and to increase parental self-efficacy regarding at-home management of their child's atopic dermatitis through improved patient education methods.

\section{Description of EBP Project}

\section{Project Overview}

This EBP project was conducted at a private allergy practice utilizing the patient population from five of their locations throughout the California and Washington areas. 
Four providers directly participated in the intervention, alongside the Doctor of Nursing practice (DNP) candidate, five nurses, and three medical assistants. An office manager, nursing supervisor, and the chief executive officer (CEO) were also involved for administrative support of the project. Patients less than 18 year of age with a pre-existing diagnosis of atopic dermatitis and an upcoming follow-up, allergy testing, or allergy treatment appointments were identified by the DNP candidate as potential study participants. New diagnoses of atopic dermatitis were identified by participating providers during new patient and follow-up appointments as potential participants.

During the office visit, the DNP candidate or provider would introduce the patient and caregiver to the study and determine potential participant interest. A packet of initial patient forms was given for the patient's parent to complete during the appointment after interest in voluntary participation of the study was expressed. This packet consisted of a participant demographic questionnaire, a Patient-Oriented Eczema Measurement (POEM) form to obtain a baseline eczema severity score for the patient at the time of the visit, and Parental Self-Efficacy with Eczema Care Index (PASECI) form to obtain baseline parental comfort with caring for a child with eczema (see Appendix E). At the end of the visit, the provider or DNP candidate presented the parent with a physical copy of the completed Eczema Action Plan designed by the American Academy of Dermatology (AAD), or an electronic copy, as shown in Appendix D, through the patient messaging portal. The parent also received a handout of written eczema education materials, created by the DNP student with input from the providers using materials from the National Institute of Health (NIH) and American Academy of Allergy, Asthma, \& Immunology (AAAAI) (see Appendix E). After receiving the EAP, the parent was asked to complete a 
Caregiver's Comprehension of Eczema Action Plan questionnaire (see Appendix E). The parent was also given a post-intervention packet containing a POEM form, PASECI form, and Caregiver's Comprehension of Eczema Action Plan questionnaire with instruction that the DNP candidate would follow up in six weeks. The parent was informed that another copy of these forms would be sent via the email provided on the demographics form and the clinic's online patient portal. Average response time for return of the post-intervention forms was 6.7 weeks. Pre- and post-intervention data were collected on a spreadsheet in the clinic's secure Google Drive. Completed Eczema Action Plans were scanned into the patient's charts by the nurses and medical assistants. The EAPs would be visible to providers at all clinic locations to assist with continuity of care.

\section{Measurements and Outcomes}

This EBP project used three measures to evaluate project outcomes. The first outcome to be measured was the change in eczema severity pre- and post- EAP use. This outcome would be measured using the University of Nottingham's widely accepted Patient-Oriented Eczema Measure scale, which inquiries about patient symptoms over a one-week period with the use of seven questions and a total potential score of 28 . The POEM scale was chosen due to provider familiarity within the allergy clinics. In the case of this scale, a score of 28 indicates severe eczema, while a score of zero represents no current symptoms. The next outcome to be measured was parental comfort with managing their child's eczema pre- and post- intervention. This outcome was to be measured using the Parental Self-Efficacy with Eczema Care Index, a seven-question survey using a 10-point Likert-scale, with a potential total score of 70. Ersser et al. (2015) demonstrated that their 29-item PASECI scale had "face, content and construct validity 
and reliability," (p.1483) with Cronbach's Alpha values of 0.906, 0.874, 0.915 and 0.953 across the four domains assessed when tested in a 242-parent focus group. The sevenquestion survey tool for this project has a calculated Cronbach's Alpha score of 0.96 indicating excellent internal consistency. A total score of 70 on the seven-question PASECI survey indicates total self-efficacy with a child's eczema management, while a score of zero indicates a lack of self-efficacy. The last outcome measured was the degree of parent or caregiver understanding of the presented EAP. This outcome was measured using a one question 10-point Likert-scale survey with a total potential score of 10 . The maximum score of 10 indicated complete comprehension of the EAP, while a score of zero indicated no understanding. Measurements on all three outcomes were to be taken at the time of receiving the EAP, and six weeks post-EAP.

\section{Anticipated Outcomes}

Based on the reported findings from randomized controlled trials reviewed in the literature search, there were several anticipated positive impacts of the EBP project. Short term goals following the implementation of written education materials and an EAP for pediatric patients with a diagnosis of atopic dermatitis at the allergy clinics would ideally reduce eczema severity as indicated by a reduction in POEM scores and increase parental understanding of the condition as indicated by an increase in PAESCI scores. The third goal was for there to be an adequate parental understanding of the provided EAP. Other anticipated benefits of the project that would not be directly measured included patient improvement in health literacy regarding atopic dermatitis, better control of eczema resulting in a decreased need for follow up visits due to eczema flares, and better 
continuity of care with provider use of a standardized and complete action plan and use of eczema severity index scales to gauge success of treatment protocols.

\section{PICOT Question}

In allergy clinic patients less than 18 years of age with a diagnosis of atopic dermatitis (eczema) (P), does implementing the use of written education materials to the patient's caregiver/parent in the form of an Eczema Action Plan in addition to verbal teaching (I), compared to the standard verbal teaching (C), result in a decrease in severity of patient reported eczema symptoms measured by the POEM form and increased parental self-efficacy of at-home eczema management measured by the Parental SelfEfficacy Index (O) within 6-10 weeks (T)?

\section{EBP Model}

The Iowa Model was selected as the evidence-based practice (EBP) model for implementing an Eczema Action Plan for pediatric patients with atopic dermatitis at an allergy clinic. The identified evidence-based practice project involved implementing a new eczema education process within an allergy clinic. Using the Evaluation Criteria for the EBP Model chart provided by Gawlinski and Rutledge (2008), several EBP models were compared for potential use. Upon comparison of the Iowa Model, Stetler Model, ACE Star Model and Johns Hopkins Nursing Model, the Iowa Model scored the highest against the six evaluation criteria. The Iowa Model was clear and concise, allowed quick assimilation of concepts, was comprehensive throughout, easy to use in a clinical setting, and applied well to the selected project (Gawlinski \& Rutledge, 2008). The Iowa Model has a strong emphasis on organizational process, and therefore is a good fit for guiding this EBP project (Gawlinski \& Rutledge, 2008). 


\section{Project Process Plan}

The EBP project was set into motion with a letter of support provided by the CEO and Founder of the allergy practice on March 6, 2020. The letter of support allowed for use of data from the clinic-site for an evidence-based class project and possible presentations and publications. This was followed by a letter indicating University of San Diego (USD) faculty approval on April 29, 2020. USD Institutional Review Board approval of exempt status was obtained on May 8, 2020. The DNP candidate provided staff training on proper implementation of the EBP project July 28, 2020 through July 31, 2020. Implementation of the use of written education materials and the EAP began on August 27, 2020 along with data collection. Additional provider education presented by the DNP candidate took place on September 22, 2020. A total of 24 patients from California and Washington locations volunteered to participate in this EBP project. The DNP candidate presented the opportunity to participate in the study to patients who met the inclusion criteria. Willing providers at select clinic locations completed the EAP form for enrolled patients. The DNP candidate followed up with the parent/caregiver in person, by phone, email, or patient messaging system at the end of the initial appointment to provide additional education as needed. At six weeks post intervention, participants were contacted by means of email, telephone, text message, or patient messaging system to complete post-EAP forms including the POEM, PAESCI and parental understanding of the EAP forms. 20 of the 24 enrolled patients completed the post intervention survey. Four patients were lost to follow-up for undetermined reasons. Data collection concluded January 23, 2020. Data analysis took place January 23, 2021 through January 29, 2021. 


\section{Results}

A total of 10 female and 10 male patients between the ages of nine months and 17 years participated in the study, $75 \%$ of whom were of Asian and Southeast Asian descent (see Figure 1). Breakdown of the number of patients in each age range can be found in Table $1.35 \%$ of participants had one other atopic condition, $35 \%$ had two other atopic conditions, and $20 \%$ had asthma, hayfever, and food allergies as comorbid atopic conditions (see Table 2). $70 \%$ of patients had a family history of one or more atopic conditions. 19 of the 20 study participants had pre-existing diagnosis of atopic dermatitis for more than one year (see Table 4), and only two of the participants had previously used an EAP (see Table 5).

At the initial visit, POEM scores for the 20 participants averaged an $8.6 / 28$, indicating most patients had moderate eczema. Six to nine weeks post-EAP, average POEM scores decreased to 4.1, indicating an improvement in eczema severity to mild after the use of an EAP and written education materials (see Figure 2). The most common eczema symptoms experienced for the 20 participants pre- and post-EAP were itchy skin and rough skin (see Figure 4). A reduction in the average number of days of symptoms was experienced across the patient population. PASECI average scores increased by 13.2 points, from $47.7 / 70$ to $60.9 / 70$, indicating an overall improvement in parental selfefficacy with caring for their child's eczema (see Figure 3). Parents initially felt most confident in their ability to apply moisturizer to their child with eczema. Parents noted an increased self-efficacy across all patients in all areas of eczema management 6-9 weeks post-EAP (see Figure 5), with comfort in managing infected skin having the most significant improvement post-EAP. This shows the AAD EAP's specific instructions to 
call the dermatologist with symptoms of infected skin such as skin weeping or oozing pus, painful skin, severe itching, fever, or chills helped to increase parental comfort with managing this complication. $85 \%$ of parents scored their understanding of the EAP at an 8/10 or better (see Table 6). After using the EAP for 6-9 weeks, the parent's felt that they understood the EAP even better as indicated by an increased average score of $9.65 / 10$ from 8.9/10 (see Figure 6). This indicates that the chosen EAP format was easy to understand and an effective tool for educating parents on caring for their child's eczema.

\section{Dissemination}

Collected data and results from the EBP project were presented at a stakeholder meeting which took place virtually via Google Drive Meeting on April 9, 2021 (see Appendix C). Meeting attendees included the DNP candidate, the allergy clinic's CEO and founder, clinical manager, and the USD clinical faculty. A poster summary of the project (see Appendix B) and the results were emailed out to the providers and charge nurses at all the company's clinic locations throughout California, Idaho, Oregon, and Washington. The Eczema Action Plan form and eczema handouts were included in this email and uploaded to the company's Google Drive. The findings from this EBP project were also presented to USD DNP candidates and their faculty advisors at the DNP Presentation Day event on March 4, 2021. A poster presentation of this EBP project took place at the Western Institute of Nursing (WIN) conference held virtually April 14-16, 2021 (see Appendix A).

\section{Cost-Benefit Analysis}

Current costs for the standard verbal education only for pediatric eczema patients at the allergy clinic are $\$ 0$. Total project costs for the implementation of the EAP and 
written eczema education materials for 20 study participants were approximately $\$ 528$. These costs included an estimated $\$ 480$ for salary costs related to time needed for staff training of providers, nursing staff, and medical assistants, and $\$ 48$ for printing of the patient forms. Potential financial benefits for the clinic with this intervention include being able to bill for atopic dermatitis as a problem for the visit, and potentially increase the total number of problems addressed at the visit to bill at a higher level, if appropriate. The estimated average cost of eczema treatment per year is $\$ 3,302$ per patient per year, $\$ 1,060$ of which are out of pocket costs (AAAAI, 2017 \& Zink et al., 2019). A reduction in severity of eczema symptoms due to increased caregiver understanding of the condition and a clear treatment plan could help to reduce the number of unnecessary eczema treatments and office visits due to flares and reduce the number of ineffective over-the-counter products used. In a program size of 20 patients, for every dollar spent there is an estimated $\$ 18.71$ cost savings for the patients. In a program size of 20 patients, there would be a $1771.21 \%$ ROI.

Non-financial benefits of the project include implementation of a streamlined process for managing eczema at the allergy clinics to allow for seamless transition of care between providers at these locations. More comprehensive documentation with an emphasis on patient education practices and ensuring patient understanding could improve medication adherence and as a result improve patient morale and satisfaction.

\section{Sustainability}

The low costs associated with the startup and maintenance of the project make this a promising EBP intervention to implement long-term at the allergy clinics. There is evidence to support use of an Eczema Action Plan and written education materials as a 
facility guideline for managing atopic dermatitis in the pediatric allergy setting. It is recommended for use of an EBP to be written in as a new guideline and staff training should be performed to educate all providers and medical personnel on the guideline. A charge nurse or provider should be appointed as a lead at each location to ensure proper and consistent use of the education materials for the first six months the new guideline is enforced. As patients become familiar with the EAP and receiving written materials, it will become an expectation to receive these tools at each visit.

\section{Implications for Clinical Practice}

This study confirms that the use of an EAP, when followed, can improve parental confidence in appropriately managing their child's eczema and reduce the severity of their child's eczema symptoms. Utilization of an EAP in combination with written education materials provides more comprehensive patient education which can improve medication adherence, decrease symptom severity, save money on extra appointments and treatment due to flares. Standardized patient education in the form of an EAP creates better continuity of care and the results of this study support the recommendation of writing this EBP intervention into clinic protocols for management of pediatric atopic dermatitis. It is recommended that this project be expanded to the remaining clinic locations within company, and in the future the clinic can also consider expanding these education methods to adult patients.

\section{Limitations}

Several limitations arose throughout the duration of the EBP project, a majority of which could be attributed to the COVID-19 Pandemic. Several staffing changes occurred between the time the letter of support was obtained, the time of staff training, and again 
when project implementation took place as a result of the financial burden of the pandemic. The DNP candidate was only able to enroll 24 participants, 20 of which completed the post-intervention documents. The first challenge noted in recruiting patients was that many of patients had their atopic dermatitis managed by a dermatologist or the pediatrician, so an EAP from someone other than the prescribing provider did not seem appropriate. In addition, the pandemic led to a decreased patient volume and most appointments were moved to a telehealth format. Telehealth visits tend to be shorter than physical office visits, and an increased difficulty was noted when it came obtaining patient interest and buy-in through telehealth visits when compared to physical office visits. The more hands-off nature of the telehealth visits and the extra steps involved for the patient after their appointment of having to send and receive extra documents could account for this. Another challenge with recruiting patients was that all written education materials were only provided in English. $85 \%$ of the 20 participants spoke English as their first language, while the remaining 15\% selected Mandarin and Nepali and their first languages. The final limitation noted for this EBP project was that there was no way to account for the affect that the time of year, concurrent allergy treatments, or specific allergies had on eczema severity as these data points could potentially lead to a different interpretation of the patient outcomes.

\section{Conclusion}

The use of an individualized Eczema Action Plan along with standardized written eczema education materials proved to be an effective intervention for reducing eczema severity in patients less than 18 years of age in a private allergy clinic, as indicated by a reduction in average POEM severity scores from moderate severity to mild severity 6-9 
weeks post implementation of the new education materials. These data points also showed that there was adequate parental understanding of the Eczema Action Plan, which contributed towards increased parental self-efficacy across seven different categories, as indicated by an increased average PASECI score 6-9 weeks post intervention. Both shortterm goals for this project were met. The successful completion of the short-term goals in addition to the low implementation costs, financial benefits of the project, and nonfinancial benefits of the project give support for the recommendation to keep this EBP intervention as a new guideline for managing atopic dermatitis in the pediatric population at all allergy clinics within the company. 


\section{References}

American Academy of Allergy Asthma \& Immunology. (2017, November 21). How expensive is healthcare for atopic dermatitis patients? https://www.aaaai.org/global/latest-research-summaries/New-Research-fromJACI-In-Practice/expensive-dermatitis

Brown, J., Weitz, N. W., Liang, A., Stockwell, M. S., \& Friedman, S. (2018). Does an eczema action plan improve atopic dermatitis? A single-site randomized controlled trial. Clinical Pediatrics, 57(14), 1624-1629. doi 10.1177/0009922818795906

Chilsom, S. S., Taylor, S. L., Balkrishnan, R., \& Feldman, S. R. (2008). Written action plans: Potential for improving outcomes in children with atopic dermatitis. Journal of the American Academy of Dermatology, 59(4). 677-683. https://doi.org/10.1016/j.jaad.2008.04.025

Drucker, A. M., Wang, A. R., Li, W. Q., Sevetson, E., Block, J. K., \& Qureshi, A. A. (2016). The burden of atopic dermatitis: Summary of a report for the national eczema association. Journal of Investigative Dermatology, 137, 26-30. https://doi.org/10.1016/j.jid.2016.07.012

Ersser, S. J., Cowdell, F., Latter, S., Gardiner, E., Flohr, S., Thompson, A. R., Jackson, K., Farasat, H., Ware, F., \& Drury, A. (2014). Psychological and educational interventions for atopic eczema in children (Review). Cochrane Database of Systematic Reviews, 2014(1). https://doi.org/10.1002/14651858.CD004054.pub3

Ersser, S. J., Farasat, H., Jackson, K., Gardiner, E., Sheppard, Z. A., \& Cowdell, F. (2015). Parental self-efficacy and the management of childhood atopic eczema: Development and testing of a new clinical outcome measure. British Journal of 
Dermatology, 173, 1479-1485. https://doi.org/10.1111/bjd.14175

Gawlinski, A., \& Rutledge, A. (2008). Selecting a model for evidence-based practice changes. AACN Advanced Critical Care, 19(3), 291-300. https://doi.org/10.1097/01.AACN.0000330380.41766.63

Gilliam, A. E., Madden, N., Sendowski, M., Mioduszewski, M., \& Duderstadt, K. G. (2016). Use of eczema action plans (EAPs) to improve parental understanding of treatment regimens in pediatric atopic dermatitis (AD): A randomized controlled trial. Journal of the American Academy of Dermatology, 74(2). 375-277. https://doi.org/10.1016/j.jaad.2015.08.067

Melnyk, B. M., \& Fineout-Overholt, E. (2015). Evidence-based practice in nursing \& healthcare: A guide to best practice (3rd ed.). Philadelphia: Wolters Kluwer/Lippincott Williams \& Wilkins.

Powell, K., Le Roux, E., Banks, J. P., \& Ridd, M. J. (2018). Developing a written action plan for children with eczema: a qualitative study. The British journal of general practice: the journal of the Royal College of General Practitioners, 68(667), e81-e89. https://doi.org/10.3399/bjgp17X693617

Pustisek, N., Situm, M., Zivkovic, M. V., Hadzavdic, S. L., Vurnek, M., \& Niseteo, T. (2016). The significance of structured parental educational intervention on childhood atopic dermatitis: a randomized controlled trial. European Academy of Dermatology and Venereology, 30. 806-812. https://doi.org/10.1111/jdv.13519

Rea, C. J., Tran, K. D., Jorina, M., Wenren, L. M., Hawryluk, E. B., Toomey, S. L. (2018). A randomized controlled trial of an eczema care plan. Academic Pediatrics, 18(7). 789-796. https://doi.org/10.1016/j.acap.2018.02.015 
Rea, C. J., Tran, K. D., Jorina, M., Wenren, L. M., Hawryluk, E. B., \& Toomey, S. L. (2018). Associations of eczema severity and patient knowledge with child quality of life in a pediatric primary care population. Clinical Pediatrics, 57(13). 15061514. https://doi.org/10.1177/0009922818787295

Sauder, M. B., McEvoy, A., \& Ramien, L. (2016). Prescribing success: Developing an integrated prescription and eczema action plan for atopic dermatitis. J Am Acad Dermatol, 75(6). 1281-1283. http://dx.doi.org/10.1016/j.jaad.2016.08.029

Sidbury, R., Tom, W. L., Bergman, J. N., Cooper, K. D., Silverman, R. A., Berger, T. G., Chamlin, S. L., Cohen, D. E., Cordoro, K. M., Davis, D. M., Feldman, S. R., Hanifin, J. M., Krol, A., Margolis, D. J., Paller, A. S., Schwarzenberger, K., Simpson, E. L., Williams, H. C., Elmets, C. A., . . Eichenfield, L. F. (2014). Guidelines of care for the management of atopic dermatitis. Journal of the American Academy of Dermatology,71(6). 1218-1233. https://doi.org/10.1016/j.jaad.2014.03.030

Sison, M. E. G. \& Lazo-Dizon, J. P. (2018). Effectiveness of the Eczema Action Plan (EAP) in improving the Eczema Area and Severity Index (EASI) scores among pediatric patients with atopic dermatitis: A pragmatic randomized controlled trial. Journal of the American Academy of Dermatology, 79(3). AB118. https://doi.org/10.1016/j.jaad.2018.05.498

Titler, M. G., Steelman, V. J., Budreau, G., Buckwalter, K. C., \& Goode, C. J. (2001). The Iowa model of evidence-based practice to promote quality care. Critical Care Nursing Clinics of North America, 13(4), 497-509.

https://doi.org/10.1016/S0899-5885(18)30017-0 
Zink, A. G. S., Arents, B., Fink-Wagner, A., Seitz, I. A., Mensing, U., Wettemann, N., de Carlo, G., \& Ring, J. (2019). Out-of-pocket costs for individuals with atopic eczema: A cross-sectional study in nine European countries. Acta Derm Venereol, 99(3). 263-267. https://doi.org/10.2340/00015555-3102 


\section{Tables}

Table 1

Ages of Patients in the Study

\begin{tabular}{lcc}
\hline \multicolumn{1}{c}{ Age } & Incidence & Percentage \\
\hline < 1 year & 2 & $10 \%$ \\
$1-5$ years & 8 & $40 \%$ \\
6-10 years & 5 & $25 \%$ \\
$11-15$ years & 3 & $15 \%$ \\
$15-18$ years & 2 & $10 \%$ \\
\hline
\end{tabular}

Table 2

\section{Comorbid Atopic Conditions}

\begin{tabular}{lcc}
\hline \multicolumn{1}{c}{ Condition } & Incidence & Percentage \\
\hline Asthma only & 0 & $0 \%$ \\
Hayfever only & 0 & $0 \%$ \\
Food Allergies only & 7 & $35 \%$ \\
Asthma \& Hayfever only & 0 & $0 \%$ \\
Asthma \& Food Allergies only & 1 & $5 \%$ \\
Hayfever \& Food Allergies only & 6 & $30 \%$ \\
Asthma, Hayfever \& Food Allergies & 4 & $20 \%$ \\
None & 2 & $10 \%$ \\
\hline
\end{tabular}

\section{Table 3}

Family History of Atopic Conditions

\begin{tabular}{lcc}
\hline \multicolumn{1}{c}{ Condition } & Incidence & Percentage \\
\hline Asthma only & 1 & $5 \%$ \\
Hayfever only & 5 & $25 \%$ \\
Food Allergies only & 1 & $5 \%$ \\
Asthma \& Hayfever only & 3 & $15 \%$ \\
Asthma \& Food Allergies only & 0 & $0 \%$ \\
Hayfever \& Food Allergies only & 1 & $5 \%$ \\
Asthma, Hayfever \& Food Allergies & 3 & $15 \%$ \\
None & 6 & $30 \%$ \\
\hline
\end{tabular}




\section{Table 4}

Duration of Eczema Diagnosis

\begin{tabular}{lcc}
\hline \multicolumn{1}{c}{ Duration } & Incidence & Percentage \\
\hline$<6$ months & 1 & $5 \%$ \\
$6-12$ months & 4 & $20 \%$ \\
More than one year & 15 & $75 \%$ \\
\hline
\end{tabular}

\section{Table 5}

Previous Use of Eczema Action Plan

\begin{tabular}{ccc}
\hline Prior Use of EAP & Incidence & Percentage \\
\hline Yes & 2 & $10 \%$ \\
No & 18 & $90 \%$ \\
\hline
\end{tabular}

Table 6

Caregiver Understanding of EAP at Initial Visit

\begin{tabular}{|c|c|c|}
\hline Total Score (0-10) & Incidence & Percentage \\
\hline 5 & 0 & $0 \%$ \\
\hline 6 & 1 & $5 \%$ \\
\hline 7 & 2 & $10 \%$ \\
\hline 8 & 4 & $20 \%$ \\
\hline 9 & 4 & $20 \%$ \\
\hline 10 & 9 & $45 \%$ \\
\hline
\end{tabular}




\section{Figures}

\section{Figure 1}

\section{RACE OF STUDY PARTICIPANTS}

asian $\square$ Southeast Asian (Indian) $\square$ White $\square$ Black $\square$ Other $\square$ Asian/White

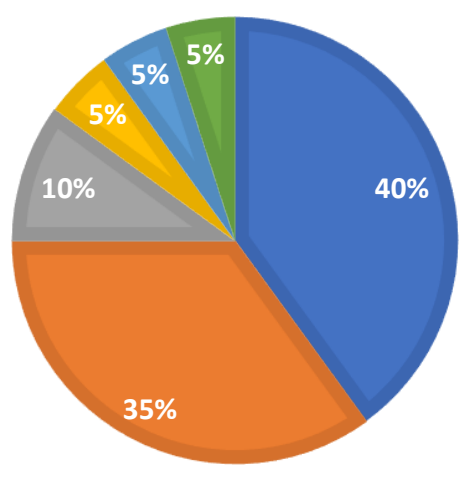

Note: Most patients included this study were of Asian and Southeast Asian (Indian) descent.

\section{Figure 2}

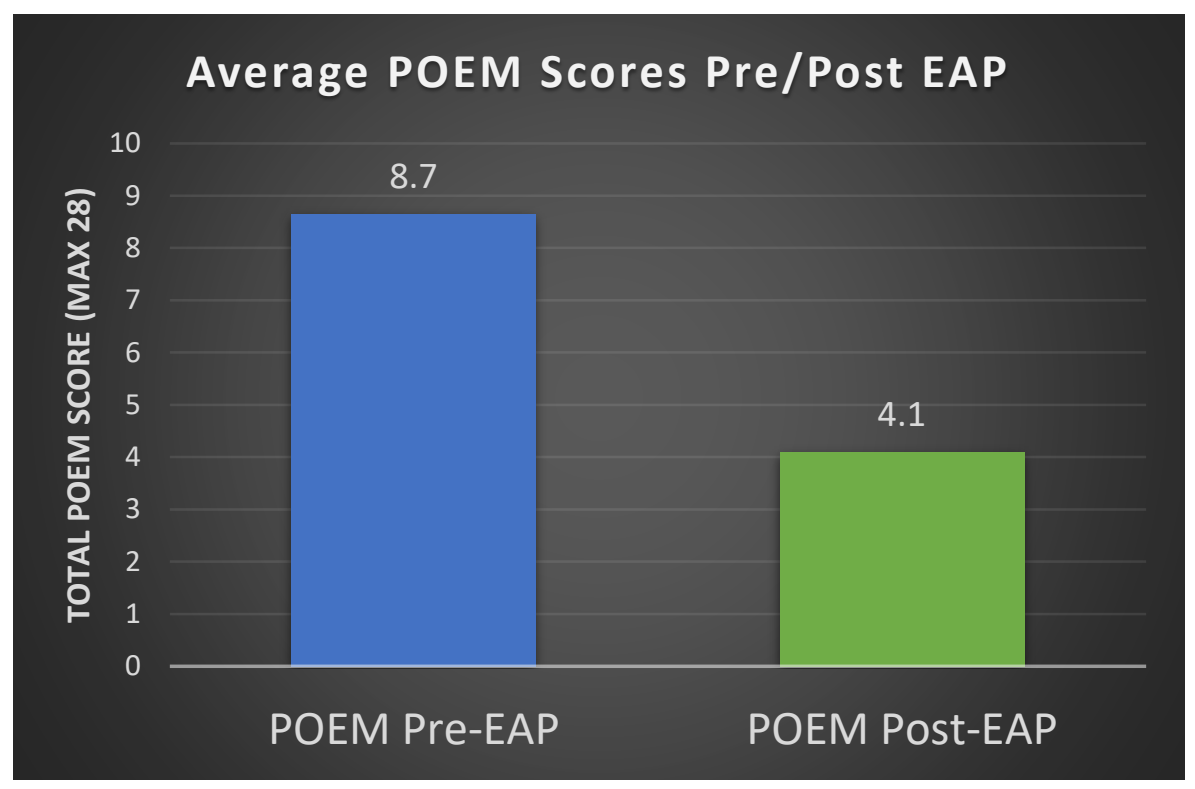

Note: POEM scores decreased by an average score of 4.1 , indicating a reduction in eczema severity 6-9 weeks post-EAP use. 


\section{Figure 3}

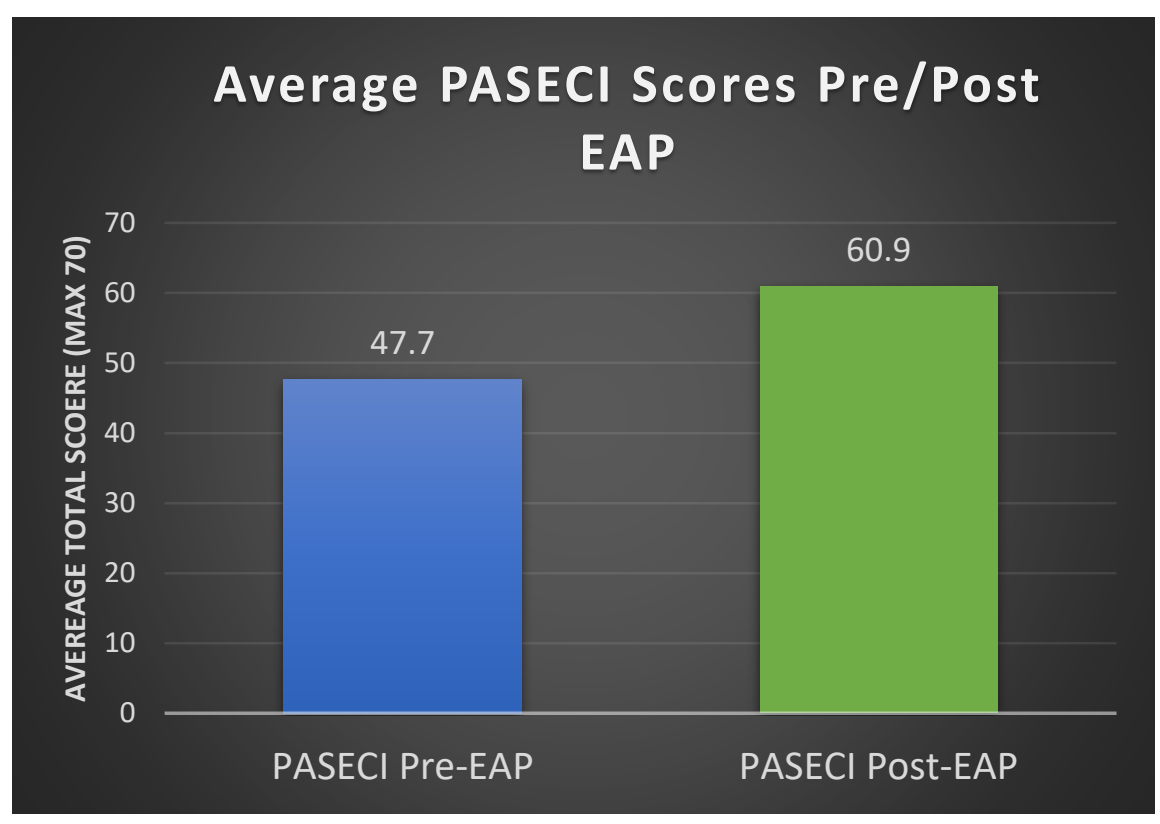

Note: PASECI average scores increased by 13.2 points, indicating an overall improvement in parental self-efficacy with caring for their child's eczema. 


\section{Figure 4}

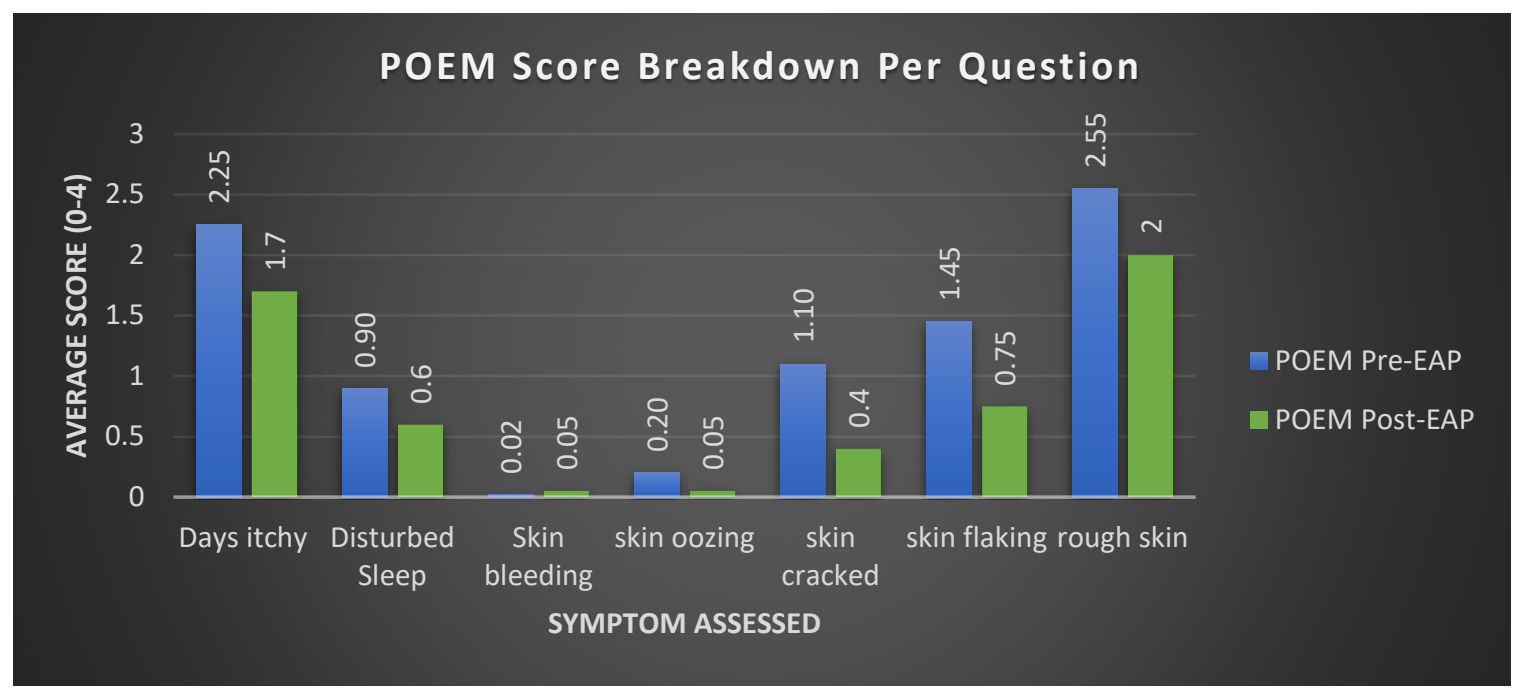

Note: The most common eczema symptoms experienced were itchy skin and rough skin.

A reduction in the average number of days of symptoms was experienced across all participants. 


\section{Figure 5}

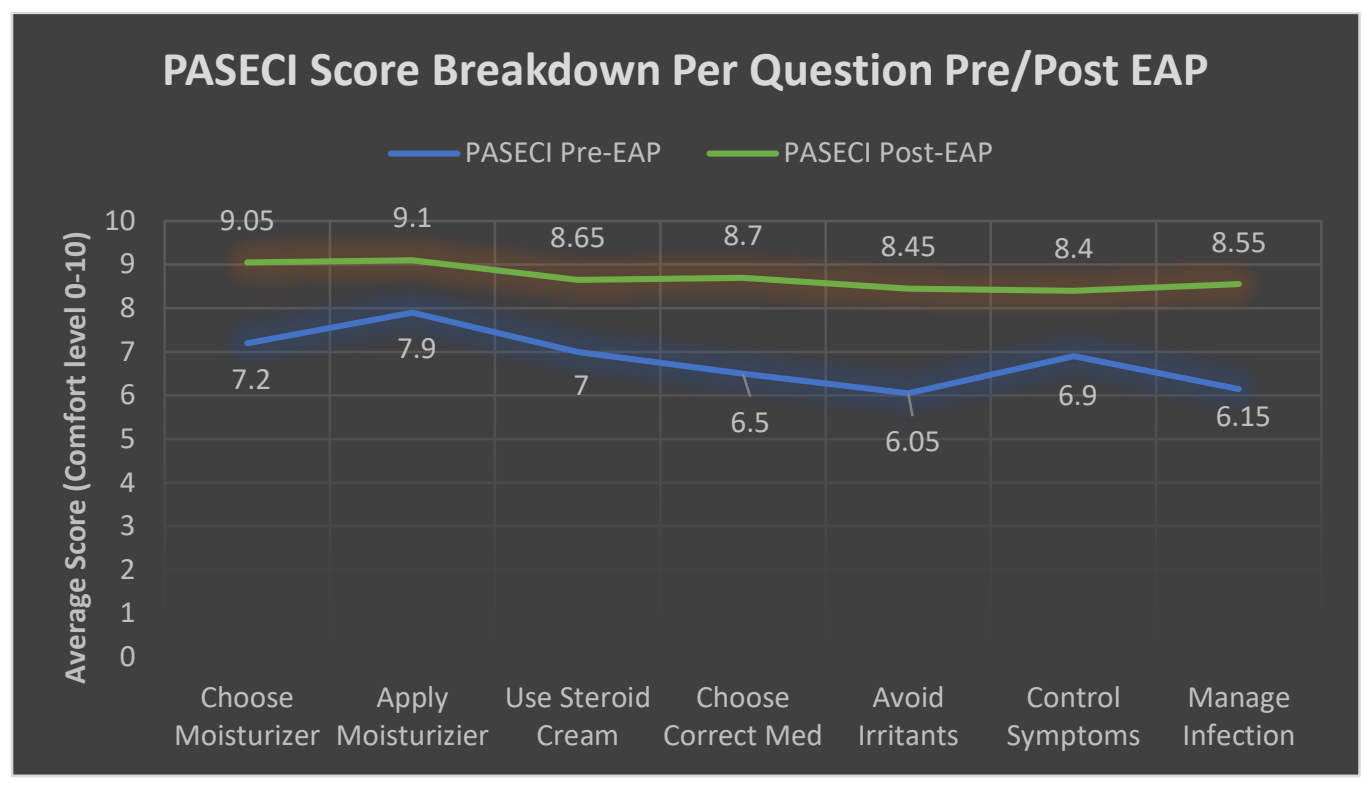

Note: Parents initially felt most confident in their self-efficacy with applying moisturizer to their child with eczema and least confident in their self-efficacy with avoiding eczema irritants. Parents noted an increased self-efficacy across the board in all areas of eczema management 6-9 weeks post-EAP. 


\section{Figure 6}

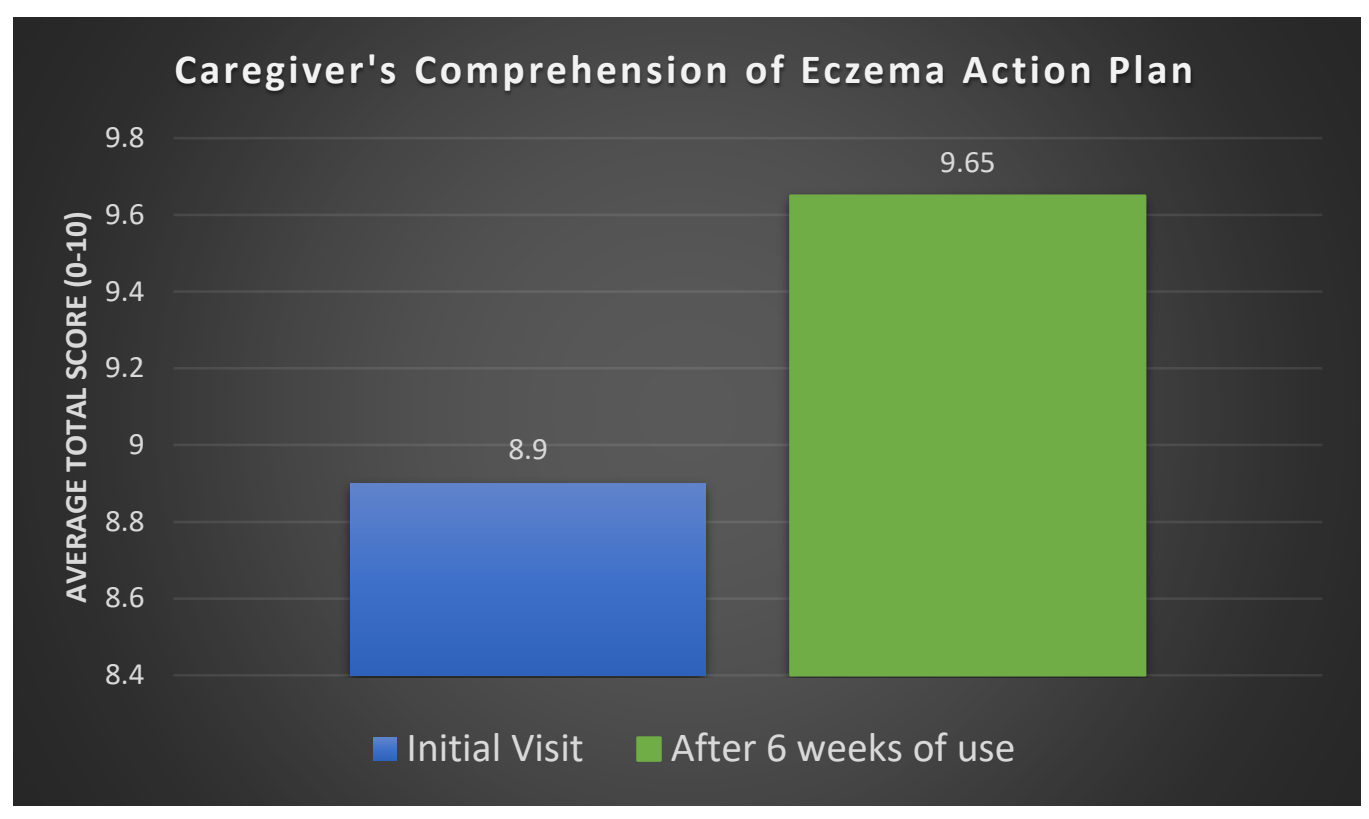

Note: On average, parents scored 8.9/10 for their understanding of the Eczema Action

Plan after immediately receiving the EAP. After using the EAP for 6-9 weeks, the parent's felt that they understood the EAP even better as indicated by an average score of $9.65 / 10$. 


\section{Appendix A}

\section{Poster Abstract with Letter of Acceptance to Conference}

\section{Abstract}

Managing Pediatric Atopic Dermatitis in the Allergy Clinic: Use of an Eczema Action Plan

Eczema, or atopic dermatitis, is a complex and chronic condition that affects approximately $10 \%$ of children throughout the United States (Brown et al., 2018). The American Academy of Allergy Asthma \& Immunology (AAAI) (2017) estimates the average cost of eczema management for each patient is approximately $\$ 3,302$ per year. The complex nature of atopic dermatitis indicates a need for individualized treatment plans. Research has shown that standardized patient teaching, written education materials, and Eczema Action Plans (EAP) reinforce patient teaching, parental understanding, and improve quality of life. This evidence-based practice project introduces the use of a written EAP, using the template created by the American Academy of Dermatology (AAD), for patients less than 18 years of age at multiple allergy clinics in California and Washington. The implemented clinical intervention included providing an individualized EAP, in addition to standardized written education materials about eczema and its treatment compiled into one handout from the National Institute of Health (NIH) and the AAAI to the parent or caregiver of the pediatric patient. Patient outcomes were measured using the University of Nottingham's validated Patient Oriented Eczema Measure (POEM) form and parental outcomes were measured using Parental Self-Efficacy Care Index (PAESCI) survey at the introduction of the EAP and again at 6-8-weeks post-intervention. Results are pending. Benefits of EAPs along with 
written education materials include reduction of patient costs on office visits and medications due to flares, improved medication adherence, improved patient and caregiver understanding, and improved patient quality of life. Use of an EAP within an allergy clinic can also allow for better continuity of care between the patient's primary care providers and the allergists.

Keywords: eczema action plan, pediatric atopic dermatitis, allergy, caregiver selfefficacy, POEM, PASECI

Letter of Acceptance

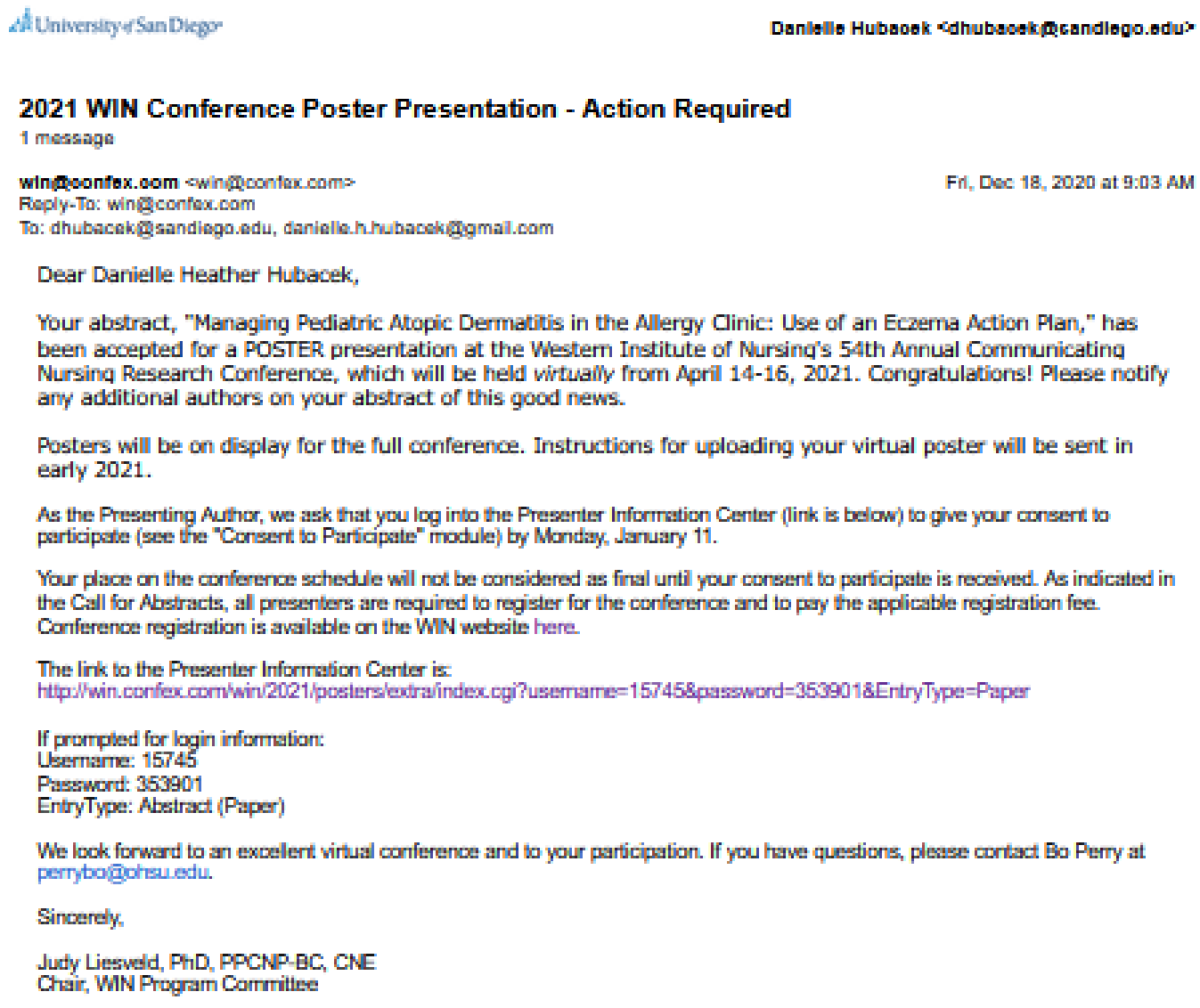




\section{Appendix B}

\section{Poster Presentation}

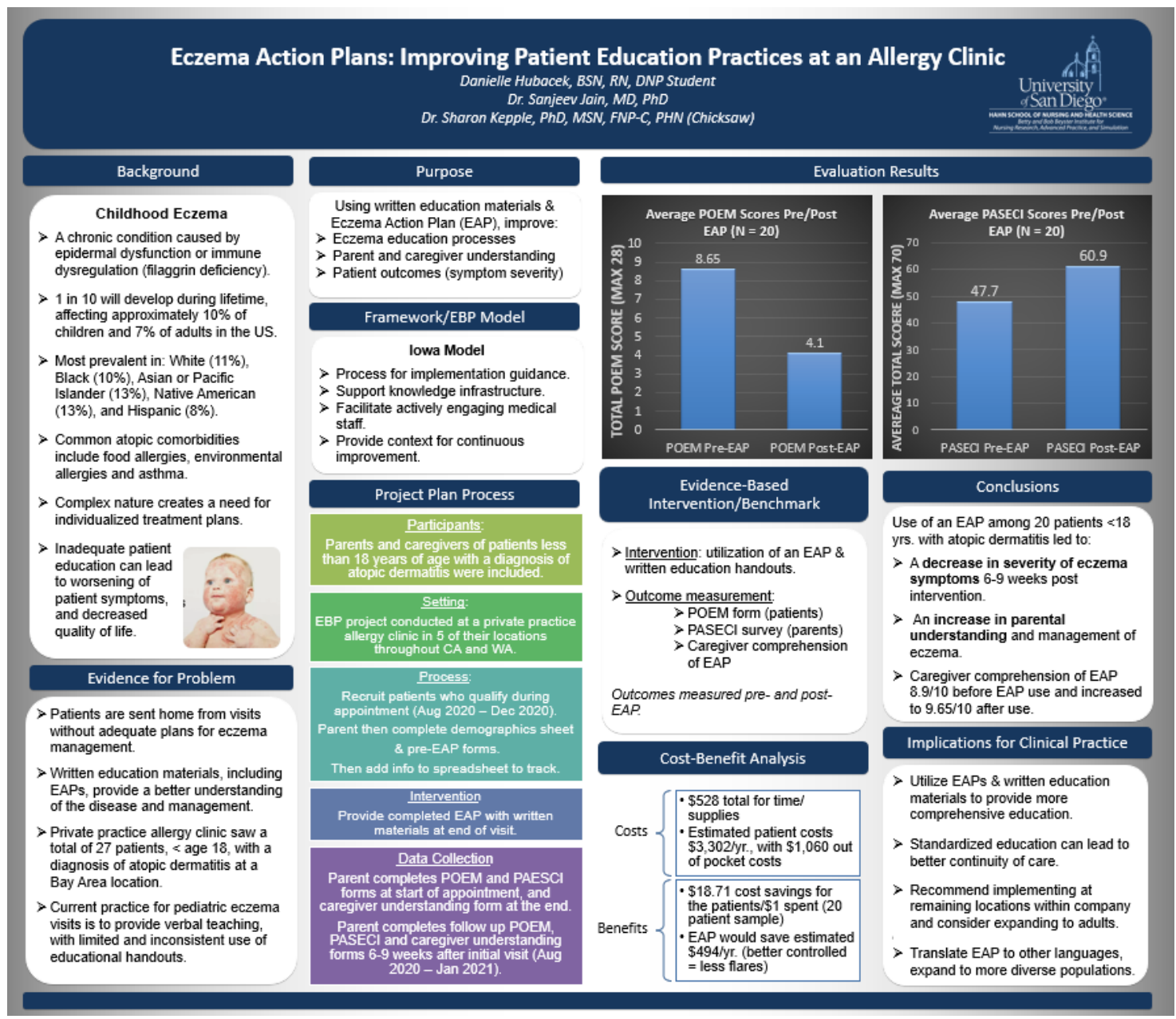




\section{Appendix C}

PowerPoint Stakeholder Presentation

\section{Stakeholder Presentation}

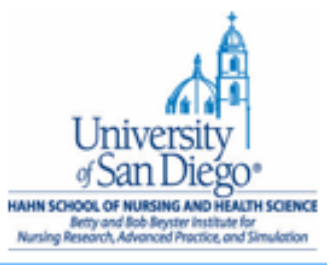

\section{Managing Atopic Dermatitis in the Allergy Clinic:} Use of an Eczema Action Plan to Increase Caregiver Understanding and Self-Efficacy

\section{Danielle Hubacek, BSN, RN, DNP Student}

Faculty Advisor:

Sharon B. Kepple, PhD, MSN,FNP-C, PHN (Chickasaw)

\section{University of San Diego}

\section{Background \& Significance}

\section{Eczema}

Chronic condition affecting $10 \%$ of children and $7 \%$ of adults in the US

$>1$ in 10 will develop during lifetime

$>$ Most prevalent in: White (11\%), Black (10\%), Asian or Pacific Islander $(13 \%)$, Native American (13\%), and Hispanic (8\%)

> Complex nature, need for individualized treatment plans

$>$ Inadequate patient education can lead to decreased symptom control and quality of life

$>$ Jan. 2020 Columbia Asthma \& Allergy Clinic FR/OL had 27 peds patients w/ eczema $\rightarrow$ all received verbal education only

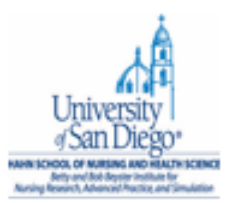




\section{Synopsis of the Evidence}

\section{Author(s) \\ Name of article}

Ersser, Cowdell, Latter, Gardiner, Flohr,

Thompson., Jackson, Farasat, Ware, \& Drury (2014). Psychological and educational interventions for atopic eczema in children (Review).

Sidbury et al. (2014). Guidelines of care for the management of atopic dermatitis.

Sison, \& Lazo-Dizon (2018). Effectiveness of the Eczema Action Plan (EAP) in improving the

Eczema Area and Severity Index (EASI) scores among pediatric patients with atopic dermatitis: A pragmatic randomized controlled trial.

Brown, Weitz, Liang, Stockwell, \& Friedman (2018). Does an eczema action plan improve atopic dermatitis? A single-site randomized controlled trial.

Gilliam, Madden, Sendowski, Mioduszewski, \& Duderstadt, (2016). Use of eczema action plans (EAPs) to improve parental understanding of treatment regimens in pediatric atopic dermatitis (AD): A randomized controlled trial.
Evidence Summary of Evidence - key bullet Ranking points quality of life and decreased eczema symptoms across several studies

- Written action plans reinforce teaching

Level 1 - Recommend nurse-led educations due to limited provider time

Level 2 - Eczema severity improved 4 weeks post EAP use

- Quality of life improved

Level 2 - Parents had increased understanding of AD treatment $\rightarrow 100 \%$ would like continued use

Level 2 parents were more confident managing their child's AD over time with use of EAP

\section{Framework/EBP Model}

\section{Iowa Model}

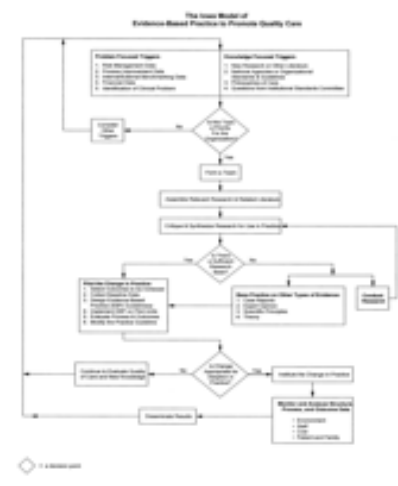

\section{Rationale:}

Provides process for implementation guidance

Support knowledge infrastructure

Facilitate actively engaging medical staff

Provide context for continuous improvement 


\section{PICO(T) Question}

$\mathbf{P}:$ In an allergy clinic with pediatric patients less than 18 years of age with a diagnosis of atopic dermatitis (eczema)

I : Does implementing the use of written education materials to the patient's caregiver/parent in the form of an Eczema Action Plan in addition to verbal teaching

C : Compared to the standard verbal teaching of eczema management

$\mathrm{O}:$ Result in a decrease in severity of patient eczema symptoms and increased parental self-efficacy of at-home management

T : Within 6-10 weeks

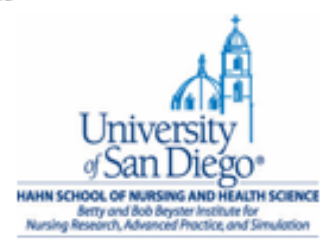

\section{Baseline Data}

Previous Use of Eczema Action Plan

\begin{tabular}{|c|c|c|}
\hline Prior Use of EAP & Incidence & Percentage \\
\hline Yes & 2 & $10 \%$ \\
\hline No & 18 & $90 \%$ \\
\hline
\end{tabular}

Caregiver Understanding of EAP at Initial Visit

\begin{tabular}{|c|c|c|}
\hline Total Score (0-10) & Incidence & Percentage \\
\hline 5 & 0 & $0 \%$ \\
\hline 6 & 1 & $5 \%$ \\
\hline 7 & 2 & $10 \%$ \\
\hline 8 & 4 & $20 \%$ \\
\hline 9 & 4 & $20 \%$ \\
\hline 10 & 9 & $45 \%$ \\
\hline
\end{tabular}




\section{Results of Outcomes}
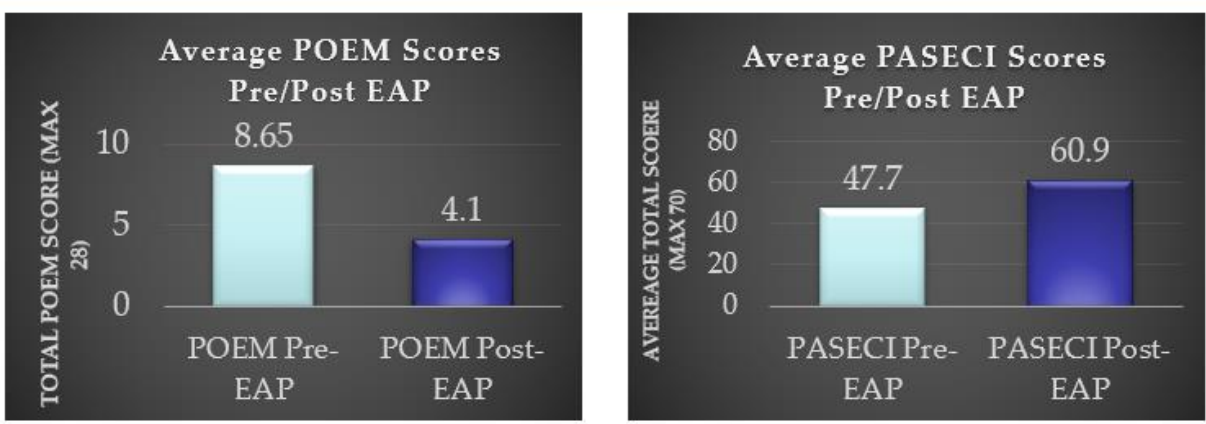

\section{Results Continued}

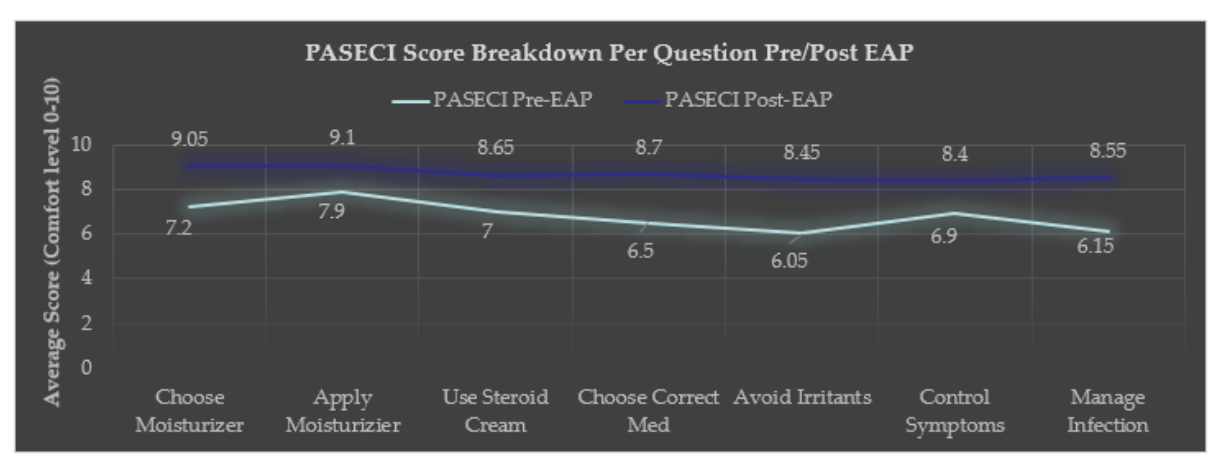

University

of SanDiego

HAHN SCHOOL OF NUESING AND HEALTH SCIENCE

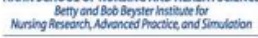
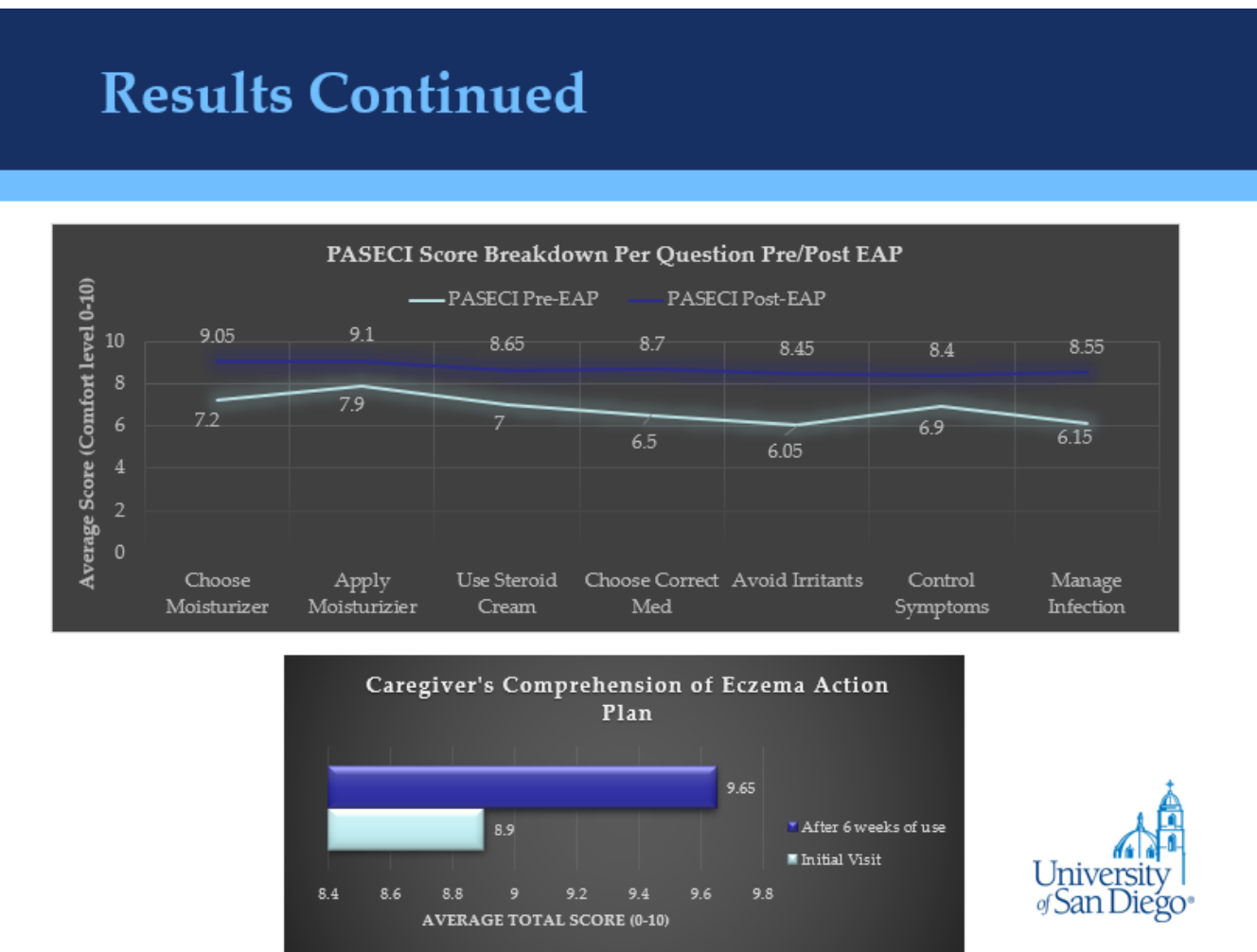

University

of San Diego" 


\section{Cost-Benefit}
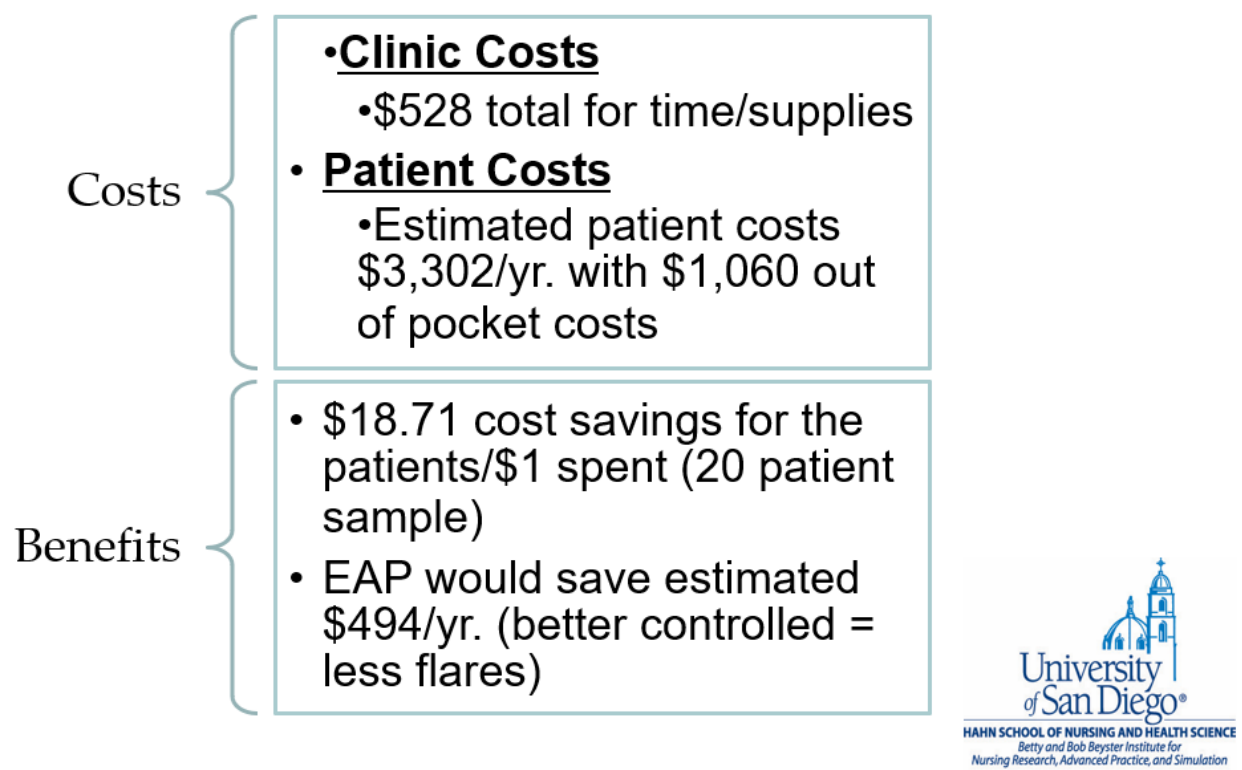

\section{Implications for Clinical Practice \& Sustainability}

Utilize EAPs \& written education materials to provide more comprehensive patient education

o improve med adherence

- decrease symptom severity

- save money on extra appts and treatment due to flares

Standardized education creates better continuity of care $\rightarrow$ write into clinic protocols

$>$ Recommend implementing at remaining locations within company and consider expanding to adults

$>$ Also recommend providing materials in other languages

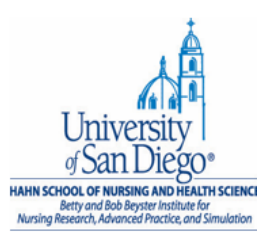




\section{Poster}

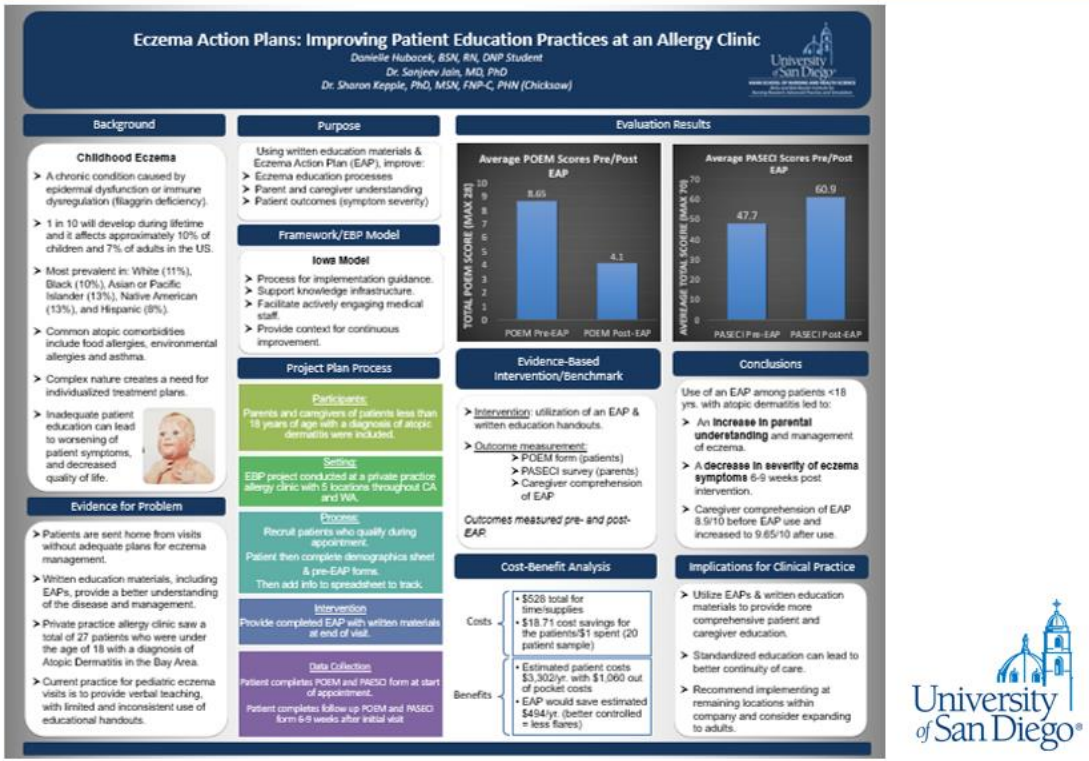

\section{Key References}

Brown, J., Weitz, N. W., Liang, A., Stockwell, M. S., \& Friedman, S. (2018). Does an eczema action plan improve atopic dermatitis? A single-site randomized controlled trial. Clinical Pediatrics 57(14). 1624-1629. doi 10.1177/0009922818795906

Ersser, S. J., Cowdell, F., Latter, S., Gardiner, E., Flohr, S., Thompson, A. R., Jackson, K., Farasat, H., Ware, F., \& Drury, A. (2014). Psychological and educational interventions for atopic eczema in children (Review). Cochrane Database of Systematic Reviews, 2014(1). Art. No.: CD004054. doi: 10.1002/14651858.CD004054.pub3

Gilliam, A. E., Madden, N., Sendowski, M., Mioduszewski, M., \& Duderstadt, K. G. (2016). Use of eczema action plans (EAPs) to improve parental understanding of treatment regimens in pediatric atopic dermatitis (AD): A randomized controlled trial. Journal of the American Academy of Dermatology, 74(2). 375-277. https://doi.org/10.1016/j.jaad.2015.08.067

Sison, M. E. G. \& Lazo-Dizon, J. P. (2018). Effectiveness of the Eczema Action Plan (EAP) in improving the Eczema Area and Severity Index (EASI) scores among pediatric patients with atopic dermatitis: A pragmatic randomized controlled trial. Journal of the American Academy of Dermatology, 79(3). AB118. https://doi.org/10.1016/j.jaad.2018.05.498

Sidbury, R., Tom, W. L., Bergman, J. N., Cooper, K. D., Silverman, R. A., Berger, T. G., Chamlin, S. L., Cohen, D. E., Cordoro, K. M., Davis, D. M., Feldman, S. R., Hanifin, J. M., Krol, A., Margolis, D. J., Paller, A. S., Schwarzenberger, K., Simpson, E. L., Williams, H. C., Elmets, C. A., ... Eichenfield, L. F. (2014). Guidelines of care for the management of atopic dermatitis. Journal of the American Academy of Dermatology, 71(6). 1218-1233. doi: 10.1016/j.jaad.2014.03.030

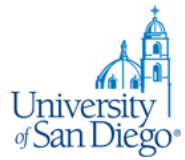




\section{Appendix D}

\section{DNP Program Outcomes Exemplars}

\begin{tabular}{|c|c|c|}
\hline $\begin{array}{l}\text { AACN DNP Essentials \& } \\
\text { NONPF Competencies }\end{array}$ & $\begin{array}{c}\text { USD DNP } \\
\text { Program } \\
\text { Objectives }\end{array}$ & Exemplars \\
\hline $\begin{array}{l}\text { DNP Essential I: Scientific } \\
\text { Underpinnings for } \\
\text { Practice } \\
\text { NONPF: Scientific } \\
\text { Foundation Competencies } \\
\text { The scientific foundation of } \\
\text { nursing practice has expanded } \\
\text { and includes a focus on both the } \\
\text { natural and social sciences } \\
\text { including human biology, } \\
\text { genomics, science of therapeutics, } \\
\text { psychosocial sciences, as well as } \\
\text { the science of complex } \\
\text { organizational structures. In } \\
\text { addition, philosophical, ethical, } \\
\text { and historical issues inherent in } \\
\text { the development of science create } \\
\text { a context for the application of } \\
\text { the natural and social sciences }\end{array}$ & $\begin{array}{l}\text { 2. Synthesize } \\
\text { nursing and other } \\
\text { scientific and } \\
\text { ethical theories and } \\
\text { concepts to create } \\
\text { a foundation for } \\
\text { advanced nursing } \\
\text { practice. }\end{array}$ & $\begin{array}{l}\text { Developed a scientific } \\
\text { understanding of human biology } \\
\text { and disease processes through an } \\
\text { Advanced Pathophysiology } \\
\text { course (ANPC 520, Fall 2018) } \\
\text { - Explored the history of } \\
\text { vaccinations, incidence and } \\
\text { prevalence of disease and } \\
\text { relevant historical information } \\
\text { related to health care through an } \\
\text { Epidemiology course (DNPC } \\
\text { 625, Fall 2018) } \\
\text { - Gained an understanding of how } \\
\text { to synthesize research related to } \\
\text { health care and utilize evidence- } \\
\text { based practice through a } \\
\text { Methods of Translational } \\
\text { Science course (DNPC 611, Fall } \\
\text { 2018) } \\
\text { Developed a scientific } \\
\text { understanding of pharmacology } \\
\text { and best practice in prescribing } \\
\text { medications about multiple } \\
\text { conditions in a Pharmacology in } \\
\text { Health Management course } \\
\text { (ANPC 523, Spring 2019) } \\
\text { Demonstrated an understanding } \\
\text { of reflective practice and } \\
\text { professional development in } \\
\text { advance practice nursing through } \\
\text { discussions, readings, and } \\
\text { practice with written narratives } \\
\text { (DNPC 610, Summer 2019) } \\
\text { patients with multi-system } \\
\text { disease states through a mock }\end{array}$ \\
\hline
\end{tabular}




\begin{tabular}{|c|c|c|}
\hline $\begin{array}{l}\text { NP Essential I: Scientific } \\
\text { Underpinnings for } \\
\text { Practice } \\
\text { NONPF: Scientific } \\
\text { Foundation Competencies }\end{array}$ & $\begin{array}{l}\text { 2. Synthesize } \\
\text { nursing and other } \\
\text { scientific and } \\
\text { ethical theories and } \\
\text { concepts to create } \\
\text { a foundation for } \\
\text { advanced nursing } \\
\text { practice. }\end{array}$ & $\begin{array}{l}\text { genetic case conference } \\
\text { presentation and Evidence-Based } \\
\text { Synthesis \& Pathogenesis } \\
\text { Presentation \& Manuscript } \\
\text { (DNPC 622, Fall 2019) } \\
\text { - Gained knowledge of } \\
\text { developmental and health } \\
\text { screening methods across the } \\
\text { lifespan and appropriate patient } \\
\text { interview techniques and applied } \\
\text { these concepts within the context } \\
\text { of a Primary Care Clinical } \\
\text { Setting (NPTC 602, Fall 2019). } \\
\text { - Gained an understanding of how } \\
\text { to appropriately assess all body } \\
\text { systems of patients throughout } \\
\text { the lifespan to gain subjective } \\
\text { and objective information } \\
\text { needed to create an assessment } \\
\text { and plan. Practiced application } \\
\text { of these skills through weekly } \\
\text { labs, OSCEs, and the primary } \\
\text { care clinical setting (APNC 521, } \\
\text { Fall 2019) } \\
\text { - Continued to build a foundation } \\
\text { of primary care theory through } \\
\text { lecture, OSCEs, and hands-on } \\
\text { application of common acute and } \\
\text { chronic conditions throughout } \\
\text { the lifespan for each body } \\
\text { system at a primary care clinical } \\
\text { site (NPTC 604, Spring } 2020 \text { ) } \\
\text { - Continued to build a foundation } \\
\text { of primary care theory through } \\
\text { lecture and OSCEs on pediatric, } \\
\text { neuro, OB/GYN, hematologic, } \\
\text { endocrine, metabolic, } \\
\text { pulmonary, and cardiac } \\
\text { conditions as well as topics such } \\
\text { as ethical principles to managing } \\
\text { patients with advanced stage } \\
\text { heart failure, maintaining } \\
\text { privacy during telehealth, } \\
\text { nutrition management (NPTC } \\
\text { 605, Summer 2020) } \\
\text { Continued to build a foundation }\end{array}$ \\
\hline
\end{tabular}




\begin{tabular}{|c|c|c|}
\hline $\begin{array}{l}\text { NP Essential I: Scientific } \\
\text { Underpinnings for } \\
\text { Practice } \\
\text { NONPF: Scientific } \\
\text { Foundation Competencies }\end{array}$ & $\begin{array}{l}\text { 2. Synthesize } \\
\text { nursing and other } \\
\text { scientific and } \\
\text { ethical theories and } \\
\text { concepts to create } \\
\text { a foundation for } \\
\text { advanced nursing } \\
\text { practice. }\end{array}$ & $\begin{array}{l}\text { of primary care theory through } \\
\text { lecture and OSCEs on eye, } \\
\text { orthopedic, cardiac, neurologic, } \\
\text { women's health, GI, male GU, } \\
\text { and dermatologic conditions } \\
\text { (NPTC 608, Summer 2020) } \\
\text { - Continued to build on the } \\
\text { foundation for conditions } \\
\text { managed in primary care through } \\
\text { theory, OSCEs, and clinical } \\
\text { application of common complex } \\
\text { and/or unstable acute and } \\
\text { chronic health problems across } \\
\text { the lifespan (NPTC } 609, \text { Spring } \\
\text { 2021) }\end{array}$ \\
\hline $\begin{array}{l}\text { DNP Essential II: } \\
\text { Organizational \& System } \\
\text { Leadership for Quality } \\
\text { Improvement \& Systems } \\
\text { Thinking } \\
\text { NONPF: Leadership } \\
\text { Competencies/Health } \\
\text { Delivery System } \\
\text { Competencies } \\
\text { Advanced nursing practice } \\
\text { includes an organizational and } \\
\text { systems leadership component } \\
\text { that emphasizes practice, ongoing } \\
\text { improvement of health outcomes, } \\
\text { and ensuring patient safety. } \\
\text { Nurses should be prepared with } \\
\text { sophisticated expertise in } \\
\text { assessing organizations, } \\
\text { identifying system's issues, and } \\
\text { facilitating organization wide } \\
\text { changes in practice delivery. This } \\
\text { also requires political skills, } \\
\text { systems thinking, and the business } \\
\text { and financial acumen needed for } \\
\text { the analysis of practice quality } \\
\text { and costs. }\end{array}$ & $\begin{array}{l}\text { 5. Design, } \\
\text { implement, and } \\
\text { evaluate ethical } \\
\text { health care } \\
\text { delivery systems } \\
\text { and information } \\
\text { systems that meet } \\
\text { societal needs and } \\
\text { ensure } \\
\text { accountability for } \\
\text { quality outcomes. }\end{array}$ & $\begin{array}{l}\text { Built a foundation for tools and } \\
\text { processes involved in quality } \\
\text { improvement in health care and } \\
\text { strategic planning through a } \\
\text { Strategic Planning and Quality } \\
\text { Initiatives Course. Applied this } \\
\text { knowledge through an individual } \\
\text { project analyzing a case study } \\
\text { regarding overuse of antibiotics } \\
\text { (DNPC 626, Spring 2019). } \\
\text { - Built a foundation of awareness } \\
\text { of Health Policy and how to } \\
\text { become involved through a } \\
\text { Health Policy course (DNPC } \\
\text { 658, Spring 2019). Within this } \\
\text { course submitted a policy } \\
\text { proposal to the ANA regarding } \\
\text { overuse of medical tests } \\
\text { Worked towards improving } \\
\text { patient care using reflective } \\
\text { practice (DNPC 610, Summer } \\
\text { 2019). Gaining the ability to } \\
\text { critically reflect on my own } \\
\text { actions and experiences has } \\
\text { allowed me to connect with my } \\
\text { patient and lead a team more } \\
\text { effectively. } \\
\text { Developed a business plan for a } \\
\text { product/service to improve } \\
\text { current health care practices }\end{array}$ \\
\hline
\end{tabular}




\begin{tabular}{|c|c|c|}
\hline $\begin{array}{l}\text { DNP Essential II: } \\
\text { Organizational \& System } \\
\text { Leadership for Quality } \\
\text { Improvement \& Systems } \\
\text { Thinking } \\
\text { NONPF: Leadership } \\
\text { Competencies/Health } \\
\text { Delivery System } \\
\text { Competencies }\end{array}$ & $\begin{array}{l}\text { 5. Design, } \\
\text { implement, and } \\
\text { evaluate ethical } \\
\text { health care } \\
\text { delivery systems } \\
\text { and information } \\
\text { systems that meet } \\
\text { societal needs and } \\
\text { ensure } \\
\text { accountability for } \\
\text { quality outcomes. }\end{array}$ & $\begin{array}{l}\text { including evaluation of current } \\
\text { and similar product/services and } \\
\text { presented the idea to peers and } \\
\text { professors (DNPC 653, Summer } \\
\text { 2019) } \\
\text { - Created a sample evidence-based } \\
\text { practice project including } \\
\text { conducting a literature review } \\
\text { and critically evaluating the } \\
\text { evidence, writing a PICOT } \\
\text { question, researching } \\
\text { conferences available to present } \\
\text { the results to, and creating a } \\
\text { mock stakeholder presentation } \\
\text { (DNPC 686, Spring 2020) } \\
\text { - Gained experience in ensuring } \\
\text { patient safety while caring for } \\
\text { patients with common conditions } \\
\text { in a primary care setting through } \\
\text { an understanding of red flag } \\
\text { symptoms for common } \\
\text { conditions, ethical principles, } \\
\text { and informed consent (NPTC } \\
\text { 604, Spring 2020) } \\
\text { Continued to develop leadership } \\
\text { skills through review of ethical } \\
\text { principles, APRN scope of } \\
\text { practice, and standards and } \\
\text { guidelines for providing clinical } \\
\text { care (NPTC 605 \& 608, Summer } \\
\text { 2020) } \\
\text { Created and implemented an } \\
\text { evidence-based practice project } \\
\text { on use of an Eczema Action Plan } \\
\text { in allergy clinics. This included } \\
\text { conducting a literature review } \\
\text { and critically evaluating the } \\
\text { evidence, writing a PICOT } \\
\text { question, implementing the use } \\
\text { of an EAP for patients }<18, \\
\text { creating a stakeholder } \\
\text { presentation, and presenting at } \\
\text { the WIN conference (DNPC } \\
\text { 630, Spring 2020-Spring 2021) }\end{array}$ \\
\hline
\end{tabular}




\begin{tabular}{|c|c|c|}
\hline $\begin{array}{l}\text { DNP Essential III: Clinical } \\
\text { Scholarship \& Analytical } \\
\text { Methods for Evidence- } \\
\text { Based Practice } \\
\text { NONPF: Quality } \\
\text { Competencies/Practice } \\
\text { Inquiry Competencies } \\
\text { Scholarship and research are the } \\
\text { hallmarks of doctoral education. } \\
\text { Although basic research is viewed } \\
\text { as the first and most essential } \\
\text { form of scholarly activity, an } \\
\text { enlarged perspective of } \\
\text { scholarship has emerged through } \\
\text { alternative paradigms that } \\
\text { involve more than discovery of } \\
\text { new knowledge. These paradigms } \\
\text { recognize: (1) the scholarship of } \\
\text { discovery and integration } \\
\text { "reflects the investigative and } \\
\text { synthesizing traditions of } \\
\text { academic life"; (2) scholars give } \\
\text { meaning to isolated facts and } \\
\text { make connections across } \\
\text { disciplines through the } \\
\text { scholarship of integration; and } \\
\text { (3) the scholar applies knowledge } \\
\text { to solve a problem via the } \\
\text { scholarship of application that } \\
\text { involves the translation of } \\
\text { research into practice and } \\
\text { dissemination and integration of } \\
\text { new knowledge. }\end{array}$ & $\begin{array}{l}\text { 4. Incorporate } \\
\text { research into } \\
\text { practice through } \\
\text { critical appraisal of } \\
\text { existing evidence, } \\
\text { evaluating practice } \\
\text { outcomes, and } \\
\text { developing } \\
\text { evidence-based } \\
\text { practice guidelines. }\end{array}$ & $\begin{array}{l}\text { Gained an understanding of how } \\
\text { to synthesize research related to } \\
\text { health care and utilize evidence- } \\
\text { based practice through a } \\
\text { Methods of Translational } \\
\text { Science course. Applied this } \\
\text { knowledge through a term paper } \\
\text { which discussed the analysis of } \\
\text { articles regarding food allergy } \\
\text { testing and utilized evidence- } \\
\text { based practice to suggest } \\
\text { implementation of early food } \\
\text { allergy detection in at-risk } \\
\text { children (DNPC 611, Fall } 2018 \text { ) } \\
\text { Built a foundation for tools and } \\
\text { processes involved in quality } \\
\text { improvement in health care and } \\
\text { strategic planning through a } \\
\text { Strategic Planning and Quality } \\
\text { Initiatives Course. Applied this } \\
\text { knowledge through an individual } \\
\text { project analyzing a case study } \\
\text { regarding evidence-based } \\
\text { changes to be made to reduce the } \\
\text { overuse of antibiotics (DNPC } \\
\text { 626, Spring 2019). } \\
\text { Developed a business plan for a } \\
\text { food allergy kit after analyzing } \\
\text { the current food allergy market } \\
\text { and products to improve current } \\
\text { food allergy practices including } \\
\text { evaluation of current and similar } \\
\text { products and presented the idea } \\
\text { to peers and professors (DNPC } \\
\text { 653, Summer 2019) } \\
\text { Researched, synthesized, and } \\
\text { presented Evidence-Based } \\
\text { guidelines and up-to-date } \\
\text { information on the pathogenesis } \\
\text { of selected conditions guide } \\
\text { peers in the evaluation of } \\
\text { disents with multi-system } \\
\text { - }\end{array}$ \\
\hline
\end{tabular}




\begin{tabular}{|c|c|c|}
\hline $\begin{array}{l}\text { DNP Essential III: Clinical } \\
\text { Scholarship \& Analytical } \\
\text { Methods for Evidence- } \\
\text { Based Practice } \\
\text { NONPF: Quality } \\
\text { Competencies/Practice } \\
\text { Inquiry Competencies }\end{array}$ & $\begin{array}{l}\text { 4. Incorporate } \\
\text { research into } \\
\text { practice through } \\
\text { critical appraisal of } \\
\text { existing evidence, } \\
\text { evaluating practice } \\
\text { outcomes, and } \\
\text { developing } \\
\text { evidence-based } \\
\text { practice guidelines. }\end{array}$ & $\begin{array}{l}\text { screenings for adults and } \\
\text { children and recommended } \\
\text { immunizations throughout the } \\
\text { lifespan through complete } \\
\text { physical assessments performed } \\
\text { at a primary care clinical site } \\
\text { (NPTC 602, Fall 2019). } \\
\text { Gained theoretical knowledge of } \\
\text { how to properly assess all body } \\
\text { systems on patients of all ages } \\
\text { and demonstrated proper } \\
\text { technique through skills labs and } \\
\text { OSCEs. Also developed the } \\
\text { ability to critically think and } \\
\text { create a list of differential } \\
\text { diagnoses based on the objective } \\
\text { clinical findings (APNC 521, } \\
\text { Fall 2019). } \\
\text { Went through the steps of } \\
\text { developing a mock EBP project } \\
\text { based on a literature review and } \\
\text { need for improvement within a } \\
\text { theoretical clinical site. } \\
\text { Synthesized the evidence to } \\
\text { apply the research into a } \\
\text { theoretical clinical site with an } \\
\text { EBP model (DNPC 686, Spring } \\
\text { 2020). } \\
\text { Utilized current guidelines } \\
\text { supported by research to } \\
\text { promote and perform routine } \\
\text { health screenings during } \\
\text { complete physical exams within } \\
\text { conditions, and dermatologic } \\
\text { knowledge of pathophysiology, } \\
\text { pharmacology, and assessment } \\
\text { skills to develop a list of } \\
\text { differential diagnoses and } \\
\text { understanding of primary care } \\
\text { conditions. Also applied these } \\
\text { concepts to perform OSCEs on } \\
\text { Women's health, respiratory } \\
\text { conding } 605 \text { \& } 608,\end{array}$ \\
\hline
\end{tabular}




\begin{tabular}{|c|c|c|}
\hline $\begin{array}{l}\text { DNP Essential III: Clinical } \\
\text { Scholarship \& Analytical } \\
\text { Methods for Evidence- } \\
\text { Based Practice } \\
\text { NONPF: Quality } \\
\text { Competencies/Practice } \\
\text { Inquiry Competencies }\end{array}$ & $\begin{array}{l}\text { 4. Incorporate } \\
\text { research into } \\
\text { practice through } \\
\text { critical appraisal of } \\
\text { existing evidence, } \\
\text { evaluating practice } \\
\text { outcomes, and } \\
\text { developing } \\
\text { evidence-based } \\
\text { practice guidelines. }\end{array}$ & $\begin{array}{l}\text { Summer 2020) Also applied this } \\
\text { knowledge to come up with a lis } \\
\text { of meaningful differential } \\
\text { diagnoses within the laser \& } \\
\text { cosmetic dermatology clinical } \\
\text { setting (NPTC } 605 \text { \& 608, Fall } \\
\text { 2020) } \\
\text { - Gained a theoretical knowledge } \\
\text { of practice guidelines for } \\
\text { common complex and/or } \\
\text { unstable acute and chronic health } \\
\text { problems including the PERC } \\
\text { rule, Ottawa Ankle and Knee } \\
\text { rules, Well's Criteria, SF } \\
\text { Syncope, Canadian C-Spine, } \\
\text { NEXUS, New Orleans CT Rule, } \\
\text { Sgarbossa's Criteria, PECARN } \\
\text { and more (NPTC 609, Spring } \\
\text { 2021) } \\
\text { Created and implemented an } \\
\text { evidence-based practice project } \\
\text { on use of an Eczema Action Plan } \\
\text { in allergy clinics. This included } \\
\text { conducting a literature review } \\
\text { and critically evaluating the } \\
\text { evidence, writing a PICOT } \\
\text { question, implementing the use } \\
\text { of an EAP for patients < 18, } \\
\text { creating a stakeholder } \\
\text { presentation, and presenting at } \\
\text { the WIN conference (DNPC } \\
\text { 630, Spring 2020-Spring 2021) }\end{array}$ \\
\hline $\begin{array}{l}\text { DNP Essential IV: } \\
\text { Information } \\
\text { Systems/Technology \& } \\
\text { Patient Care Technology } \\
\text { for Improvement \& } \\
\text { Transformation of Health } \\
\text { Care } \\
\quad \text { NONPF: } \\
\text { Technology \& Information } \\
\text { Literacy Competencies }\end{array}$ & $\begin{array}{l}\text { 7. Incorporate } \\
\text { ethical, regulatory, } \\
\text { and legal } \\
\text { guidelines in the } \\
\text { delivery of health } \\
\text { care and the } \\
\text { selection, use, and } \\
\text { evaluation of } \\
\text { information } \\
\text { systems and } \\
\text { patient care } \\
\text { technology. }\end{array}$ & $\begin{array}{l}\text { - Built a foundation regarding the } \\
\text { rules, regulations, and } \\
\text { application of healthcare } \\
\text { informatics through an } \\
\text { Introduction to Health Care } \\
\text { Information Management } \\
\text { course. Gained hands-on } \\
\text { experience utilizing Microsoft } \\
\text { Excel as a tool to be used within } \\
\text { the health-care system (HCIN } \\
\text { 540, Spring 2019) }\end{array}$ \\
\hline
\end{tabular}




\begin{tabular}{|c|c|c|}
\hline $\begin{array}{l}\text { DNP graduates are distinguished } \\
\text { by their abilities to use } \\
\text { information systems/technology to } \\
\text { support and improve patient care } \\
\text { and health care systems, and } \\
\text { provide leadership within health } \\
\text { care systems and/or academic } \\
\text { settings. Knowledge and skills } \\
\text { related to information } \\
\text { systems/technology and patient } \\
\text { care technology prepare the DNP } \\
\text { graduates apply new knowledge, } \\
\text { manage individual and aggregate } \\
\text { level information, and assess the } \\
\text { efficacy of patient care } \\
\text { technology appropriate to a } \\
\text { specialized area of practice along } \\
\text { with the design, selection, and use } \\
\text { of information systems/technology } \\
\text { to evaluate programs of care, } \\
\text { outcomes of care, and care } \\
\text { systems. Information } \\
\text { systems/technology provide a } \\
\text { mechanism to apply budget and } \\
\text { productivity tools, practice } \\
\text { information systems and decision } \\
\text { supports, and webbased learning } \\
\text { or intervention tools to support } \\
\text { and improve patient care.. }\end{array}$ & $\begin{array}{l}\text { 7. Incorporate } \\
\text { ethical, regulatory, } \\
\text { and legal } \\
\text { guidelines in the } \\
\text { delivery of health } \\
\text { care and the } \\
\text { selection, use, and } \\
\text { evaluation of } \\
\text { information } \\
\text { systems and } \\
\text { patient care } \\
\text { technology. }\end{array}$ & 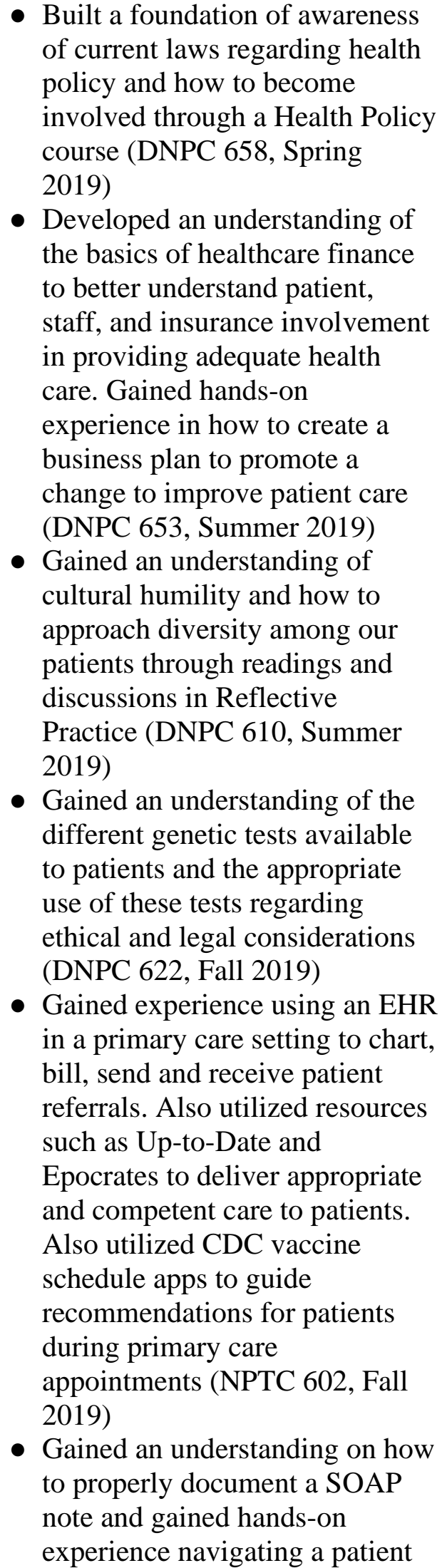 \\
\hline
\end{tabular}




\begin{tabular}{|c|c|c|}
\hline $\begin{array}{l}\text { DNP Essential IV: } \\
\text { Information } \\
\text { Systems/Technology \& } \\
\text { Patient Care Technology } \\
\text { for Improvement \& } \\
\text { Transformation of Health } \\
\text { Care } \\
\qquad \quad \text { NONPF: } \\
\text { Technology \& Information } \\
\text { Literacy Competencies }\end{array}$ & $\begin{array}{l}\text { 7. Incorporate } \\
\text { ethical, regulatory, } \\
\text { and legal } \\
\text { guidelines in the } \\
\text { delivery of health } \\
\text { care and the } \\
\text { selection, use, and } \\
\text { evaluation of } \\
\text { information } \\
\text { systems and } \\
\text { patient care } \\
\text { technology }\end{array}$ & $\begin{array}{l}\text { chart through OSCEs in our } \\
\text { simulation lab (APNC 521, Fall } \\
\text { 2019) } \\
\text { - Created a theoretical EBP } \\
\text { project that utilized patient } \\
\text { technology services such as a } \\
\text { patient portal to share and collect } \\
\text { data with patients (DNPC 686, } \\
\text { Spring 2020) } \\
\text { - Continued to use an EHR in a } \\
\text { primary care setting to chart, } \\
\text { bill, send and receive patient } \\
\text { referrals and utilized Up-to-Date } \\
\text { and Epocrates to deliver } \\
\text { appropriate and competent care } \\
\text { to patients. Also used the CDC } \\
\text { milestones app, USPSTF and } \\
\text { ASCVD apps as resources to } \\
\text { guide clinical practice (NPTC } \\
\text { 604, Spring 2020) } \\
\text { - Developed an understanding of } \\
\text { Telehealth practice theories } \\
\text { through lecture content (NPTC } \\
\text { 605, Summer 2020) and clinical } \\
\text { application (NPTC 604, Spring } \\
\text { 2020 \& NPTC 605/608, Fall } \\
\text { 2020). Also developed a } \\
\text { foundation for diagnostic } \\
\text { interpretations of x-ray imaging } \\
\text { (NPTC 605 \& 608, Summer } \\
\text { 2020). } \\
\text { - Dained experience providing } \\
\text { ethical and compassionate care } \\
\text { to care to low-income and at-risk } \\
\text { populations including patients } \\
\text { with HIV, AIDS, HCV, and } \\
\text { substance abuse disorders at a } \\
\text { primary care clinical setting } \\
\text { (NPTC 609, Spring 2021) } \\
\text { lasers to treat common understanding of } \\
\text { dermatologic conditions (NPTC } \\
\text { 605 } 608, \text { Fall 2020) } \\
\text { (N) }\end{array}$ \\
\hline
\end{tabular}




\begin{tabular}{|c|c|c|}
\hline $\begin{array}{l}\text { DNP Essential V: Health } \\
\text { Care Policy for Advocacy } \\
\text { in Health Care } \\
\text { NONPF: Policy } \\
\text { Competencies } \\
\text { Health care policy, whether } \\
\text { created through governmental } \\
\text { actions, institutional decision- } \\
\text { making, or organizational } \\
\text { standards, creates a framework } \\
\text { that can facilitate or impede the } \\
\text { delivery of health care services or } \\
\text { the ability of the provider to } \\
\text { engage in practice to address } \\
\text { health care needs. Engagement in } \\
\text { the process of policy development } \\
\text { is central to creating a health } \\
\text { care system that meets the needs } \\
\text { of its constituents. Political } \\
\text { activism and a commitment to } \\
\text { policy development are central } \\
\text { elements of DNP practice. }\end{array}$ & $\begin{array}{l}\text { 3. Demonstrate } \\
\text { leadership in } \\
\text { collaborative } \\
\text { efforts to develop } \\
\text { and implement } \\
\text { policies to improve } \\
\text { health care } \\
\text { delivery and } \\
\text { outcomes at all } \\
\text { levels of } \\
\text { professional } \\
\text { practice } \\
\text { (institutional, } \\
\text { local, state, } \\
\text { regional, national, } \\
\text { and/or } \\
\text { international). }\end{array}$ & $\begin{array}{l}\text { Built a foundation of awareness } \\
\text { of Health Policy and how to } \\
\text { become involved through a } \\
\text { Health Policy course. Within this } \\
\text { course submitted a policy } \\
\text { proposal to the ANA regarding } \\
\text { overuse of medical tests. Gained } \\
\text { awareness of current } \\
\text { organizations involved in these } \\
\text { processes and how to get } \\
\text { involved (DNPC 658, Spring } \\
\text { 2019). }\end{array}$ \\
\hline $\begin{array}{l}\text { DNP Essential VI: } \\
\text { Interprofessional } \\
\text { Collaboration for } \\
\text { Improving Patient \& } \\
\text { Population Health } \\
\text { Outcomes } \\
\text { NONPF: Leadership } \\
\text { Competencies } \\
\text { Today's complex, multi-tiered } \\
\text { health care environment depends } \\
\text { on the contributions of highly } \\
\text { skilled and knowledgeable } \\
\text { individuals from multiple } \\
\text { professions. In order to } \\
\text { accomplish the IOM mandate for } \\
\text { safe, timely, effective, efficient, } \\
\text { equitable, and patient-centered } \\
\text { care in this environment, health } \\
\text { care professionals must function } \\
\text { as highly collaborative teams. } \\
\text { DNPs have advanced preparation } \\
\text { in the interprofessional dimension } \\
\text { of health care that enable them to } \\
\text { facilitate collaborative team }\end{array}$ & $\begin{array}{l}\text { 1. Demonstrate } \\
\text { advanced levels of } \\
\text { clinical practice } \\
\text { within defined } \\
\text { ethical, legal, and } \\
\text { regulatory } \\
\text { parameters in } \\
\text { designing, } \\
\text { implementing, and } \\
\text { evaluating } \\
\text { evidenced-based, } \\
\text { culturally } \\
\text { competent } \\
\text { therapeutic } \\
\text { interventions for } \\
\text { individuals or } \\
\text { aggregates. } \\
\text { 3. Demonstrate } \\
\text { leadership in } \\
\text { collaborative } \\
\text { efforts to develop } \\
\text { and implement } \\
\text { policies to improve }\end{array}$ & $\begin{array}{l}\text { - Built a foundation of awareness } \\
\text { of Health Policy and how to } \\
\text { become involved through a } \\
\text { Health Policy course (DNPC } \\
\text { 658, Spring 2019). Within this } \\
\text { course submitted a policy } \\
\text { proposal to the ANA regarding } \\
\text { overuse of medical tests } \\
\text { - Gained experience using an EHR } \\
\text { in a primary care setting to send } \\
\text { and receive patient referrals from } \\
\text { other specialties within the } \\
\text { healthcare system. Collaborated } \\
\text { with other NPs and Providers } \\
\text { within the clinic setting to } \\
\text { provide competent care to } \\
\text { patients (NPTC 602, Fall } 2019 \text { ) } \\
\text { - Collaborated with my peers in } \\
\text { developing accurate physical } \\
\text { assessment skills in the } \\
\text { simulation lab (APNC 521, Fall } \\
\text { 2019) } \\
\text { Created a theoretical DNP } \\
\text { project that required }\end{array}$ \\
\hline
\end{tabular}




\begin{tabular}{|c|c|c|}
\hline $\begin{array}{l}\text { functioning and overcome } \\
\text { impediments to interprofessional } \\
\text { practice. DNP graduates have } \\
\text { preparation in methods of } \\
\text { effective team leadership and are } \\
\text { prepared to play a central role in } \\
\text { establishing interprofessional } \\
\text { teams, participating in the work } \\
\text { of the team, and assuming } \\
\text { leadership of the team when } \\
\text { appropriate. }\end{array}$ & $\begin{array}{l}\text { health care } \\
\text { delivery and } \\
\text { outcomes at all } \\
\text { levels of } \\
\text { professional } \\
\text { practice } \\
\text { (institutional, } \\
\text { local, state, } \\
\text { regional, national, } \\
\text { and/or } \\
\text { international). }\end{array}$ & $\begin{array}{l}\text { collaboration between providers, } \\
\text { nurses, medical assistants, } \\
\text { clinical managers, and patients } \\
\text { to improve patient understanding } \\
\text { and outcomes surrounding } \\
\text { pediatric eczema management } \\
\text { (DNPC 686, Spring 2020) } \\
\text { Continued to utilize the EHR in } \\
\text { a primary care setting to send } \\
\text { and receive patient referrals from } \\
\text { other specialties within the } \\
\text { healthcare system. Collaborated } \\
\text { with other NPs and Providers } \\
\text { and medical assistants within the } \\
\text { clinic setting to provide } \\
\text { competent care to patients } \\
\text { (NPTC 604, Spring 2020) } \\
\text { Became comfortable with a team } \\
\text { approach to treating } \\
\text { dermatologic conditions with } \\
\text { lasers at Scripps Clinic } \\
\text { Dermatology through hands-on } \\
\text { collaboration with a nurse } \\
\text { practitioner and LVN. Also } \\
\text { became comfortable with } \\
\text { knowing when to refer patients } \\
\text { to general dermatology or the } \\
\text { PCP for continued management } \\
\text { of medical conditions outside the } \\
\text { lasers \& cosmetic dermatology } \\
\text { scope of practice (NPTC } 605 \& \\
608, \text { Fall } 2020 \text { ) }\end{array}$ \\
\hline $\begin{array}{l}\text { DNP Essential VII: } \\
\text { Clinical Prevention \& } \\
\text { Population Health for } \\
\text { Improving Nation's } \\
\text { Health } \\
\text { NONPF: Leadership } \\
\text { Competencies } \\
\text { Consistent with national calls for } \\
\text { action and with the longstanding } \\
\text { focus on health promotion and } \\
\text { disease prevention in nursing, the } \\
\text { DNP graduate has a foundation }\end{array}$ & $\begin{array}{l}\text { 6. Employ a } \\
\text { population health } \\
\text { focus in the design, } \\
\text { implementation, } \\
\text { and evaluation of } \\
\text { health care } \\
\text { delivery systems } \\
\text { that address } \\
\text { primary, } \\
\text { secondary, and } \\
\text { tertiary levels of } \\
\text { prevention. }\end{array}$ & $\begin{array}{l}\text { - Developed the ability to interpret } \\
\text { epidemiological data and use } \\
\text { this data to implement a primary } \\
\text { prevention program for asthma } \\
\text { in pediatric patients at public } \\
\text { school through a project } \\
\text { completed in DNPC } 625 \text { (Fall } \\
\text { 2018) } \\
\text { - Developed a foundation in health } \\
\text { promotion and prevention } \\
\text { through lecture content on social } \\
\text { determinants of health, change } \\
\text { theories, health disparities, and }\end{array}$ \\
\hline
\end{tabular}




\begin{tabular}{|c|c|c|}
\hline $\begin{array}{l}\text { in clinical prevention and } \\
\text { population health. This } \\
\text { foundation enables DNP } \\
\text { graduates to analyze } \\
\text { epidemiological, biostatistical, } \\
\text { occupational, and environmental } \\
\text { data in the development, } \\
\text { implementation, and evaluation of } \\
\text { clinical prevention and } \\
\text { population. }\end{array}$ & $\begin{array}{l}\text { 6. Employ a } \\
\text { population health } \\
\text { focus in the design, } \\
\text { implementation, } \\
\text { and evaluation of } \\
\text { health care } \\
\text { delivery systems } \\
\text { that address } \\
\text { primary, } \\
\text { secondary, and } \\
\text { tertiary levels of } \\
\text { prevention. }\end{array}$ & $\begin{array}{l}\text { the differences between primary, } \\
\text { secondary, and tertiary care. } \\
\text { Became familiar with ACOG, } \\
\text { AAP, USPSTF and their } \\
\text { recommendations for } \\
\text { preventative screenings and care } \\
\text { (NPTC 602, Fall 2019). } \\
\text { - Analyzed current eczema } \\
\text { management within an allergy } \\
\text { clinic to determine a need for } \\
\text { streamlined practice regarding } \\
\text { patient education to improve } \\
\text { patient outcomes for a mock } \\
\text { EBP project (DNPC 686, Spring } \\
\text { 2020) } \\
\text { Continued to develop a } \\
\text { foundation in health promotion } \\
\text { and prevention through lecture } \\
\text { content on bias, cross cultural } \\
\text { care, patient privacy, and ethical } \\
\text { decision making. Continued to } \\
\text { utilize ACOG, AAP, and } \\
\text { USPSTF recommendations for } \\
\text { preventative screenings in } \\
\text { primary care setting (NPTC } 604, \\
\text { Spring } 2020 \text { ). } \\
\text { Perform skin checks and } \\
\text { treatment of actinic keratoses } \\
\text { with liquid nitrogen and PDT to } \\
\text { prevent progression of the } \\
\text { lesions to skin cancer at a } \\
\text { dermatology clinical setting. } \\
\text { Also provided patient education } \\
\text { regarding proper skin care and } \\
\text { protection (NPTC } 605 \text { \& } 608, \\
\text { Fall } 2020 \text { ) }\end{array}$ \\
\hline $\begin{array}{l}\text { DNP Essential VIII: } \\
\text { Advanced Nursing } \\
\text { Practice } \\
\text { NONPF: Independent } \\
\text { Practice/Ethics } \\
\text { Competencies The increased } \\
\text { knowledge and sophistication of }\end{array}$ & $\begin{array}{l}\text { 1. Demonstrate } \\
\text { advanced levels of } \\
\text { clinical practice } \\
\text { within defined } \\
\text { ethical, legal, and } \\
\text { regulatory } \\
\text { parameters in } \\
\text { designing, } \\
\text { implementing, and }\end{array}$ & $\begin{array}{l}\text { - Gained and understanding of } \\
\text { cultural humility and how to } \\
\text { approach diversity among our } \\
\text { patients through readings and } \\
\text { discussions in Reflective } \\
\text { Practice. Also practiced } \\
\text { reflection and mindfulness } \\
\text { throughout the course to learn } \\
\text { how to provide culturally }\end{array}$ \\
\hline
\end{tabular}




\begin{tabular}{|c|c|c|}
\hline $\begin{array}{l}\text { health care has resulted in the } \\
\text { growth of specialization in } \\
\text { nursing in order to ensure } \\
\text { competence in these highly } \\
\text { complex areas of practice. The } \\
\text { reality of the growth of } \\
\text { specialization in nursing practice } \\
\text { is that no individual can master } \\
\text { all advanced roles and the } \\
\text { requisite knowledge for enacting } \\
\text { these roles. DNP programs } \\
\text { provide preparation within } \\
\text { distinct specialties that require } \\
\text { expertise, advanced knowledge, } \\
\text { and mastery in one area of } \\
\text { nursing practice. A DNP } \\
\text { graduate is prepared to practice } \\
\text { in an area of specialization within } \\
\text { the larger domain of nursing. }\end{array}$ & $\begin{array}{l}\text { evaluating } \\
\text { evidence-based, } \\
\text { culturally } \\
\text { competent } \\
\text { therapeutic } \\
\text { interventions for } \\
\text { individuals or } \\
\text { aggregates. }\end{array}$ & 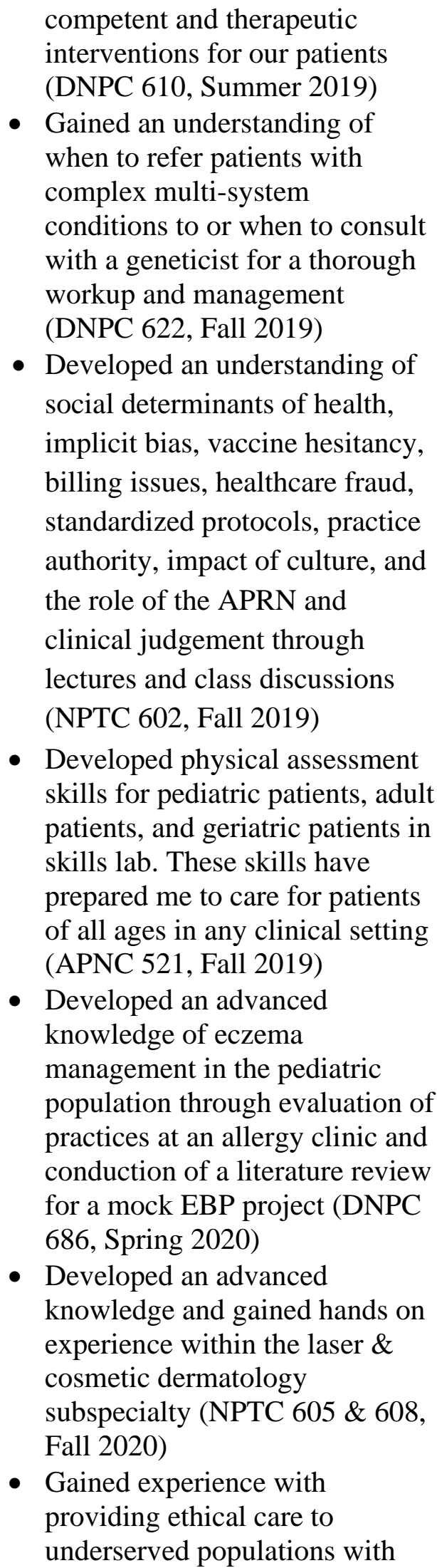 \\
\hline
\end{tabular}




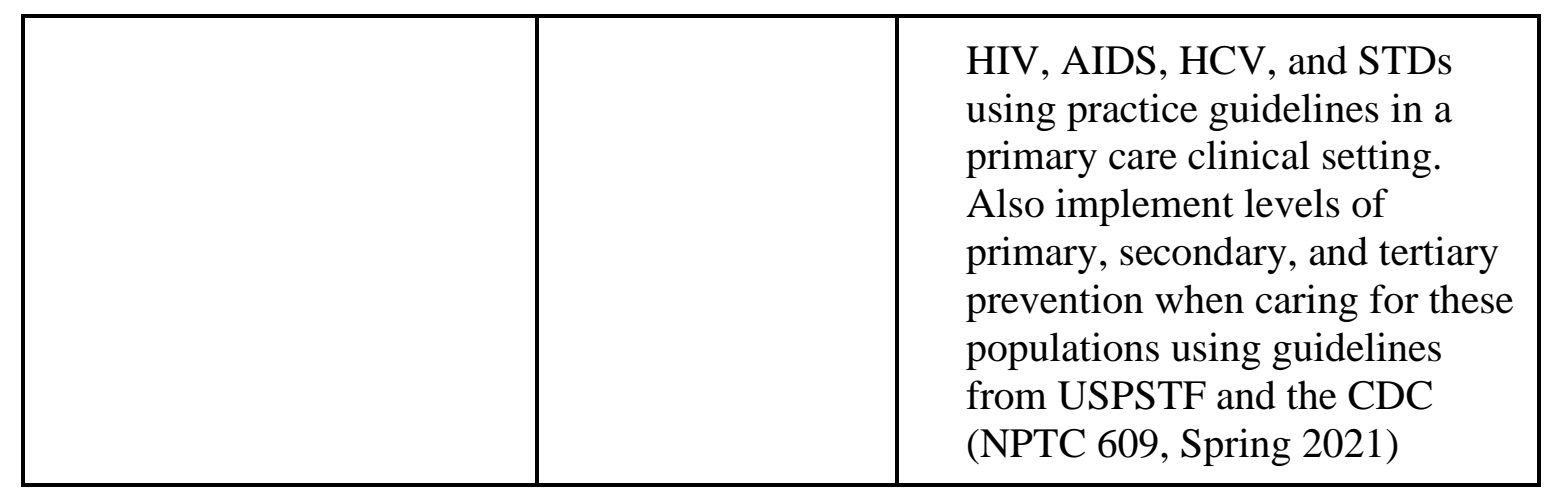




\section{Appendix E}

\section{Project Documents}

Participant Contact Information and Demographics Form

\section{Participant Contact Information and Demographics}

Dear Parent/Caregiver:

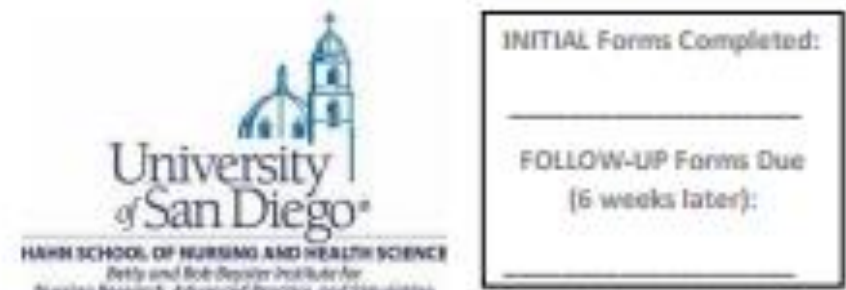

Thank you for particlpating in this important evidence-based project to manage childhood eczema. I would like to find out how well the Ecrema Action Plan (EAP) works for you and your chlid in 6 weeks.

Piease indicate how you would ake to return 2 forms 6 weeks after recelving your EAP:

- POEM (Patient-Oriented Eczema Measure)

- Parental Self-Efficacy with Eczema Care index

Take a picture of the forms and text to $(510) 579.9036$.

$\square$ Receive and complete forms through Klara Patient Messaging System

E-mail forms to daniolkheaz-clinic.com

Please provide your contact information which will remain private and will not be shared.

Parent/Caregiver Name

Phone number

E-mail address

I consent to participate in this study and follow up in 6 weeks.

X. (algn here) Date:

Thank you,

Danielle Hubacek, BSN, RN, Doctar af Nursing Practice Candidote 


\section{Demographics Questionnaire}

To be completed by parent/coregiver

Please circle your answer

1. Are you the caregher of this child?

Yes No

2. Who is filling out this form?

Parent Grandparent Relative Guardian

3. What is your age?

Less than 18 years $\quad 18-25$ years $26-35$ years $\quad 36.45$ years 46.65 years

4. Is English your primary language?

Yes No If No, what is your primary language?

5. Do you work or attend school:

Fulf-time Part-time Not currently working or attending school

6. What is the age of the child with ecaema?

7. What is the sex of the child?

Male Female

8. What is the race of the child?

White Black Hispanic Asian Other___ Prefer not to answer

9. Does the child have asthma?

Yes No

10. Does the child have Hay fever (also be referred to as allergic rhinitis or seasonal allergies)

Yes No

11. Does the child have food allergies?

Yes No

If Yes, what foods?

12. Is there any family history of:

asthma food allergies seasonal allergies none

13. Are there any smokers in the home where the child lives?

Yes No

14. How long has your child had eczema?

Less than 6 months $\quad 6-12$ months more than a year

15. Hawe you ever received an Eczema Action Plan before?

Yes No 
Patient-Oriented Eczema Measure (POEM) Form

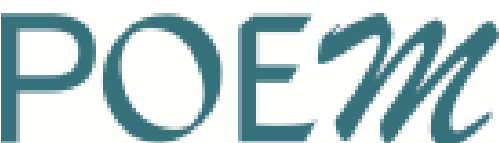

Patient-Oriented Eczema Measure

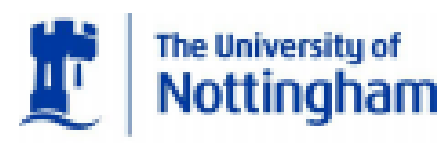

UNITED KINCDOM $=$ CHINA , MALAYSI

POEM for proxy completion (e.g by parent)

Patient Detalls:

Date:

Please circle one response for each of the seven questions below about your child's eczema. If your child is old enough to understand the questions then please fill in the questionnaire together. Flease leave blank any questions you feel unable to answer.

1. Over the last week, on how many days has your child's skin been itchy because of their eczema?

No days $\quad 1.2$ days $\quad 3-4$ days $\quad 5.6$ days Every day

2. Over the last week, on how many nights has your child's sleep been disturbed because of their eccema?

No days 1-2 days $\quad 3-4$ days $\quad 5.6$ days Every day

3. Over the last week, on how many days has your child's skin been bleeding because of their ecrema?

No days $\quad 1.2$ days $\quad 3-4$ days $\quad 5.6$ days Every day

4. Over the last week, on how many days has your chlld's skin been weeping or oozing clear fluid because of their eczema?

No days $\quad 1.2$ days $\quad 3.4$ days $\quad 5.6$ days Every day

5. Over the last week, on how many days has your child's skin been cracked because of their eczema?

No days $\quad 1.2$ days $\quad 3-4$ days $\quad 5.6$ days Every day

6. Over the last week, on how many days has your child's skin been flaking off because of their eccema?

No days $\quad 1.2$ days $\quad 3.4$ days $\quad 5.6$ days Every day

7. Over the last week, on how many days has your child's skin felt dry or rough because of their ecrema?

No days $\quad 1.2$ days $\quad 3-4$ days $\quad 5.6$ days Every day

Total POEM Score (Maximum 28): 

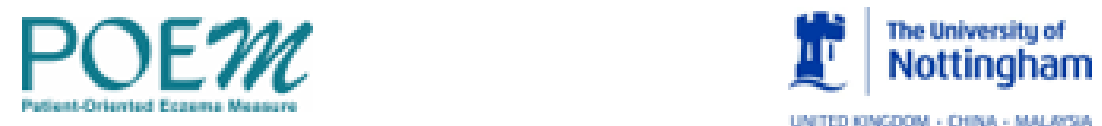

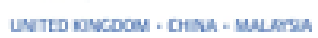

\section{POEM for self-completion and/or proxy completion}

How is the scoring done?

Each of the seven questions carries equal weight and is scored from 0 to 4 as follows:

$\begin{array}{ll}\text { No days } & =0 \\ 1-2 \text { days } & =1 \\ 3-4 \text { days } & =2 \\ 5-6 \text { days } & =3 \\ \text { Every day } & =4\end{array}$

Note:

- If one question is left unanswered this is scored 0 and the scores are summed and expressed as usual out af a maximum of 28

- If two or more questions are left unanswered the questionnaire is not scored

- If two or more response options are selected, the response option with the highest score should be recorded
What does a poem score mean?

To help patients and clinicians to understand their POEM scores, the following bandings have been established (see references below):

\begin{tabular}{|c|c|}
\hline - 0 to 2 & $=$ Clear or almost clear \\
\hline - 3 to 7 & = Mild eczema \\
\hline - 8 to 16 & = Moderate eczema \\
\hline 17 to 24 & = Severe eczema \\
\hline - 25 to 28 & = Very severe eczema \\
\hline
\end{tabular}

Do I need permission to use the scale?

Whilst the POEM scale is protected by capyright, it is freely available for use and can be downloaded from: wownottingham.accuk/dermatology We do however ask that you register your use of the POEM by e-mailing cebdinnottinghamacus with details of how you would like to use the scale, and which countries the scale will be used in.

\section{Beferences}

Charman CR, Vess Ad, Wrilaus HC. The Patient-Criented Ecaema Measare: Develogment and Initial Validatias of a New Toel lo: Meavuring Alopic Ecoema Severity from the Patients' Perspective.

Arch Dermasal. 2004,1401513-1519

Charman CR, Vesa Al, Ravenscroh JC, WIFams HC. Translating Patient-Oriented Ecae-a Measure [POEM] scores into disical practice by suggesting severify strata derived ening anchor-tased metheds.

Br J Dermasol. Dec $2013 ; 169|6|$ : $1326-1932$.

D The University of Nattingham. The Patient Driented Eczema Measure (PDEM) scale is free to use. Permiksian is granted to reproduce and/or redistribute this material in its entirety without modificatian. Any use which falls outside this remit requires the express consent of the copyright owner. 
Parental Self-Efficacy with Eczema Care Index Form

\section{Parental Self-Eflicacy with Eczema Care Index}

MARAGING MEDICATIONJECIEMA AN D SMMPTONS: How CONFIDENT do vou foel that Nou can:

1. Chooke a moisturiaer (grease) that is wulable for your child

$\begin{array}{lllllllllll}0 & 1 & 2 & 3 & 4 & 5 & 6 & 7 & 8 & 9 & 10 \\ \text { Cinnot do } & & & & & & & & & & \end{array}$

2. Successluly apply moisturiers (preas) to you child's actem

$\begin{array}{llllllllll}0 & 1 & 2 & 3 & 4 & 5 & 6 & 7 & 8 & 9\end{array}$

Cannot do

Highly certilin can do

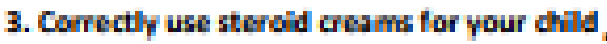

$\begin{array}{lllllllllll}0 & 1 & 2 & 3 & 4 & 5 & 6 & 7 & 8 & 9 & 10 \\ \text { Cannot do } & & & & & & & & & & \end{array}$

4. Make the right choice of medkation if the symptams of your chilfs ecaema buame worse

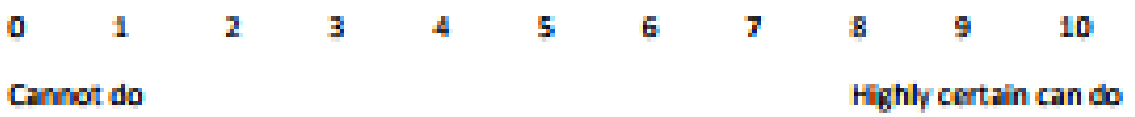

5. Mange to avod thinge that irritate/baravate your child's acum

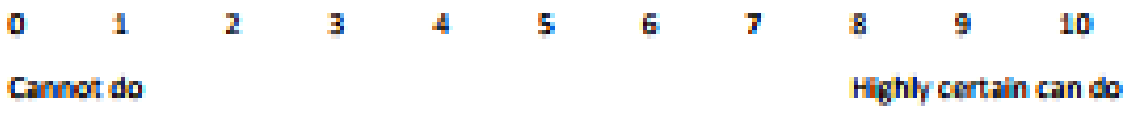

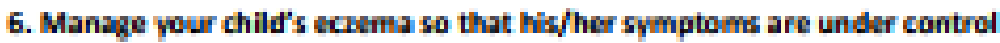

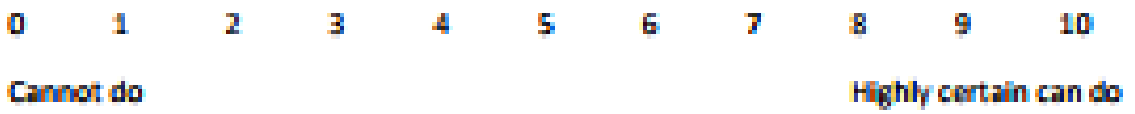

7. Know what to do if you think pour child's ecaema has becone inlectiod

Cannot do

Highly cortzin can do 


\section{Eczema Action Plan}

\section{Eczema under control}

Shin soft, supple, maybe some dryness

1 Bathe (5-10 minutes) in lukewarm weter every

2. Apply molsturizer to all skin within 3 minutes of finishing bath.

3 Apply moisturizer $\mathbf{2}$ more times during day to skin that feels dry or aften flares.

\section{Eczema flare}

Mchy sldin with redness or rash

Use your child's meclicine and moisturizer (shown below) es often as indicated.

Bathe your child (5-10 minutes) in lukewarm water every

Within 3 minutes of bathing:

- Apply child's medicine (shown below) to the eczema.

- Apply child's moésturizer, skipping areas with medicine. You don't want to apply moisturizer on tap of the medicine.

Medicine for mild flare (rednesa, same ichi)

Face

Scalp

Bedy

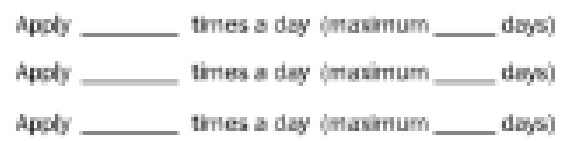

Medicine for moderate or severe flare (very itchy rashi)

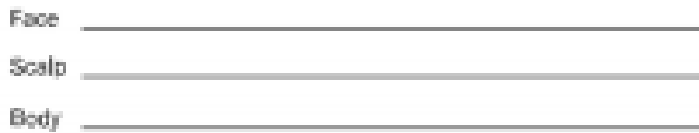

Cleanser

Use times a day

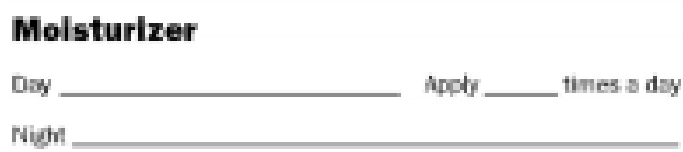

\section{other medicine}

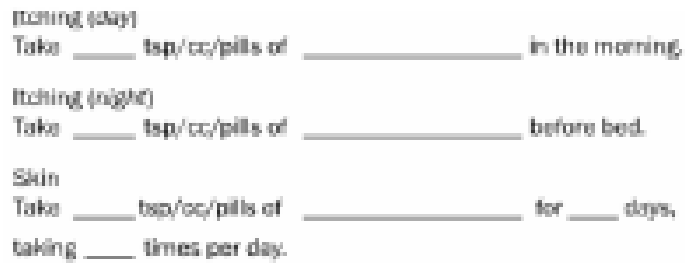

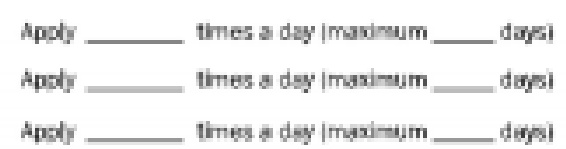
times a day | maximejim deysi

i

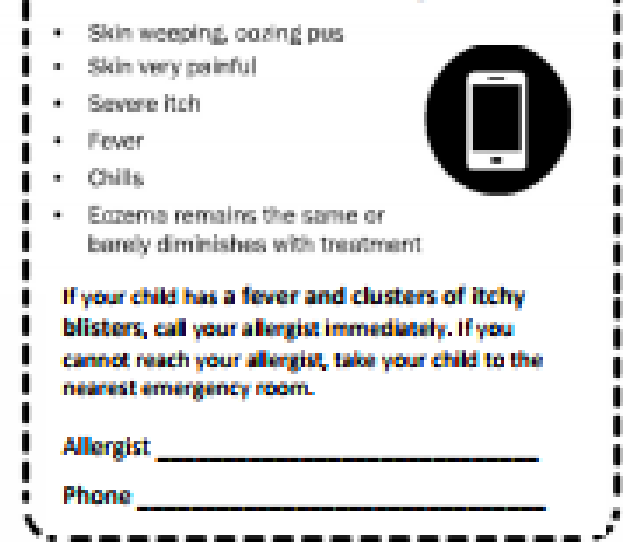




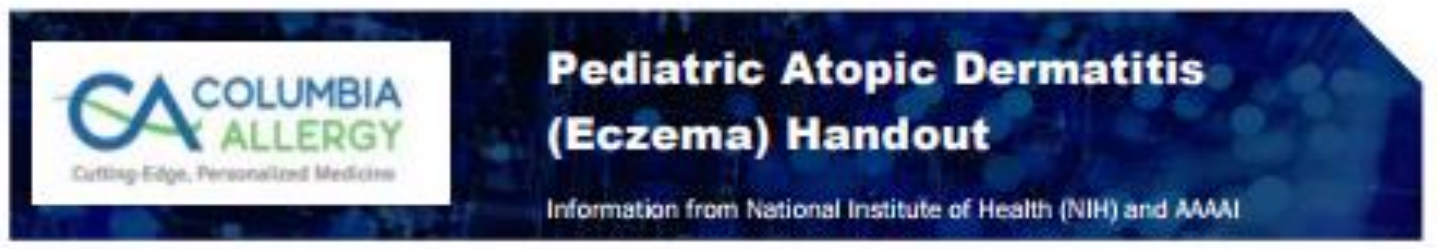

\section{Atoplc Dermatlts (Eczema) Key Points}

Atopic dermatitis, often called eczema, is a chronic (long-lasting) disease that causes the skin to become inflamed and irritated, making it extremely itchy. This condition usually begins in childhood; however, anyone can get the disease. Eczema is NOT spread from person to person.

The exact cause of eczema is unknown, but most agree that the condition is related to the immune system and that genetics play a fole in who gets it. Living with atopic dermatitis can be hard, but treatment with medications and skin care can help control symptoms.

You can help prevent flares of atopic dermatitis by caring for your skin and following your provider's Ecrema Action Plan.

\section{Symptoms of Atoplc Dermatitls \\ - Raneso from milld to severe}

- dry patches of skin

- rashes that may coze. weep clear fluid, or bleed or may become infected when scratched

- thickening and hardening of the skin

The rash can appear anywhere on the body. The symptoms can flare in multiple spots at a time and can affect sleep and daily living.

\section{Management Goals}

- Manage \& control dry skín

- Stop more skin from becoming inflamed

- Control itching

- Promote healing

- Prevent flares \& infections from itching

\section{What is Atopic Dermatitis?}

Atopic dermatitis is a chronic disease that causes the skin to become inflamed and irritated, making it extremely itchy. Scratching can lead to:

- Redness, swelling, cracking, "weeping" clear fluid, crusting and scaling

In most cases, there are times when the disease is worse, called flares, followed by times when the shin improves or clears up entirely, called remissions.

Although the exact cause of ecrema is unknown, most agree that the condition develops in the immune system and that it is often genetically determined.

Recent studies have shown that some patients with eczema lack proteirs that are important for a normal skin barrier. This leaves the skin unprotected from irritants such as allergers, harsh skin products, and bacteria that can trigger an immune response causing the skin to itch.

\section{Who gets Atopic Dermattilis?}

Atopic dermatitis is a common desease, and it usually appears in babies and children. For many, atopic dermatitis goes away before the teenage years. However, some children may continue to have symptoms as teens and adults. Occasionaly, the disease first appears during adulthood.

About $13 \%$ of all children in the U.S. have atopic dermatitis. You may have a higher chanoe of developing atopic dermatitis if you have a family history of:

- Atopic dermatitis

- Hay fever

- Asthma

- Food allergies 


\section{Eczema Management}

Eczema can often be "trisgered" by external factors, 50 it is important to work towards avoiding these triggers and maintaining a good skin routine. Some general tips to avoid flares include:

- Use mild, unscented detergents for washing clothes and avoid dryer sheets and wash al new clothes prior to wearing.

- Moid harsh, drying, and scented soaps and known allergens

- Keep affected skin covered whenever possible to avoid irnitation

- Use sunscreen on a regular basis and avoid sun damage to the skin.

- Keep the irside of your home at a cool, stable temperature and consistent humidity levels.
Essential Daily Treatment MOISTURIZERS

- Apply an unsoented moisturizer all over the body (not just the eczema areas) io lock in moisture EVERY DAY.

- Ointments 8 creams can be more benefidal than bions because the water in lotion evaporates quicker.

- Look for cleansers \& moisturizers with National Eczema Association's Seal of Acceptance ${ }^{\text {TW }}$ on the label. These products are intended for use by people with eczema or sensitive skin.

\section{Diluted Bleach Baths (Treatment)}

Staphylococcus aureus bacterial infections can make eczema symptoms worse. Bleach baths are sometimes recommended to reduce infection and eczems symptoms.

\section{Reclpe and Inetructions}

- Add $1 / 4 \cdot 1 / 2$ cup of common $5 \%$ household bleach to a bathtub full of water ( 40 gallors).

- Soak your torso or just the affected part of your skin for about 10 minutes.

Limit diluted bleach baths to no more than twice a week. Do not submerge your head and be very careful to avoid getting the diluted bleach into the eyes. Rinse off with fresh water and apply moisturizer.

Talk to your prowder first baftare ushe

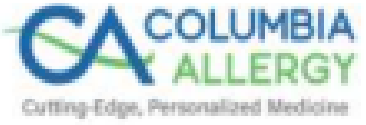

\section{Indlvlduallzed Treatment Plan}

Your provider will work with you to develop an individualized treatment plan. The treatment plans usually consist of a combination of therapies including:

- Gentle skin clearsing agents and daily moisturizers (Aquaphor, Eucerin, Vanicream, Cetaphil. Cerave, etc.)

- Prescription medications such as topical steroids, topical calcineurin inhibitors (TCls), and phosphodiesterase 4 (PDE4) inhibitors, or biologics to reduce inflammation and control symptoms

- Antihistamines for itching (may be best at bedtime)

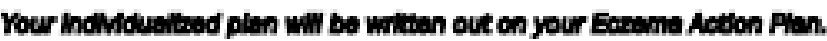
How to Track Eczoma Symptoms

The Patient Oriented Eczema Measure (POEM) is a tool used for monitoring atopi: ecsema severity using the symptoms experienced by the patient. This tool can be used during your visit to determine how severe your symptoms are and how well the treatment plan is working.

\section{Other Eczema Resources}

Mmarlean Acudangy of Demmatoloty

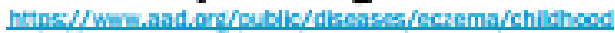

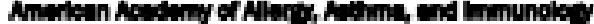

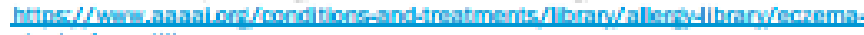
atopic-dermatitis

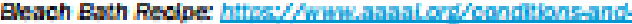

treatments/Wbrary/allergik-lbrary/bleach-bath-recipe-forskin-condklons

Nettonal Eorana Ansooletion

hitips//nationalocaema.ons/ecoema/patient-fact-shoets/

POEM Form (The University of Nottingham)

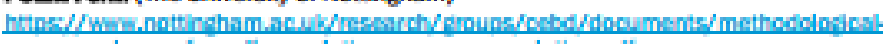

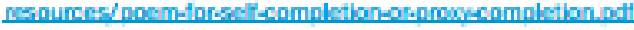

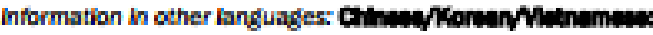

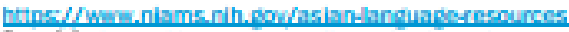

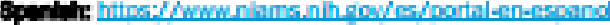


Caregiver Comprehension of Eczema Action Plan

\section{Cartghers Camprahension of Ecarma Action Plan}

1. How well do you understand your child's Ecume Action Plan? Circle a number.

$\begin{array}{lllllllllll}0 & 1 & 2 & 3 & 4 & 5 & 6 & 7 & 8 & 9 & 10\end{array}$
Ho unbustanding full understanding 


\section{Appendix F}

\section{Certificates}

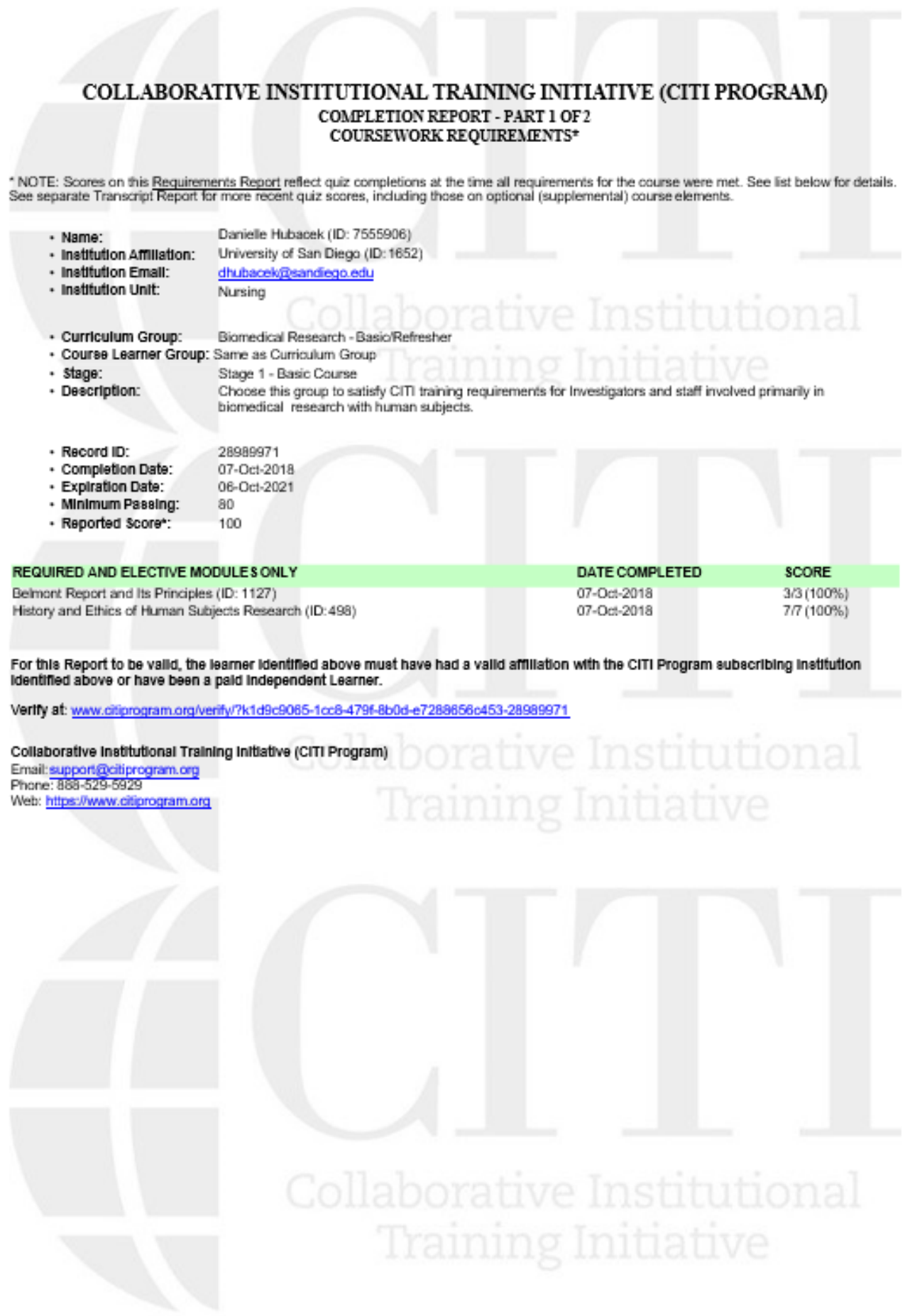


COLLABORATIVE INSTITUTIONAL TRAINIVG INITIATIVE (CIII PROGRAM) COMAIITON ERTORT - PART 2 OE 2 COERSWORK TRAYSTRIT:*

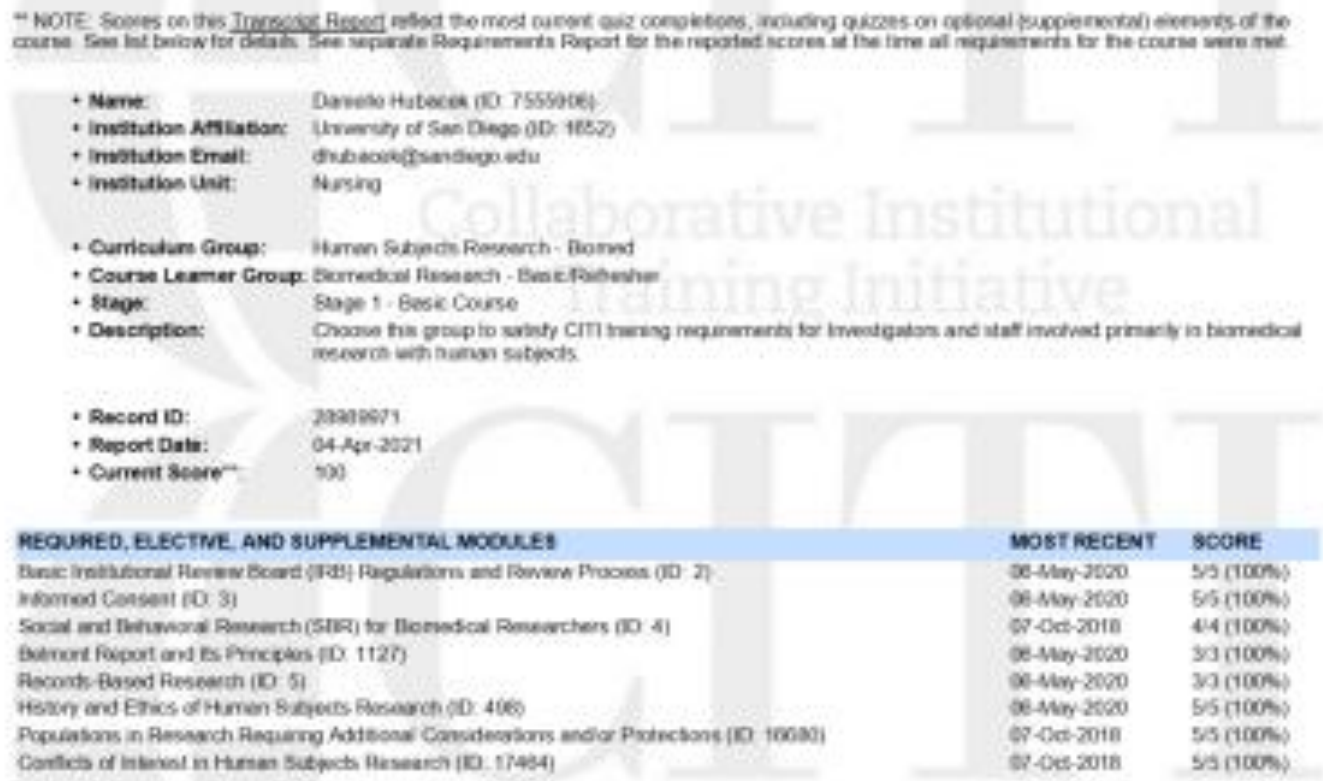

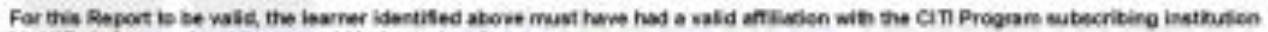

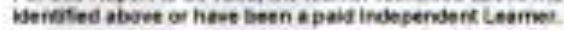

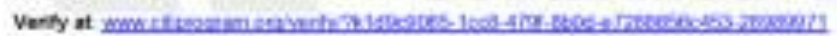

Cotoberetist insabutonal Tranirg intative jein froganj

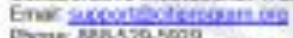

Pone Bess2500

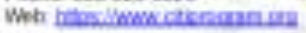
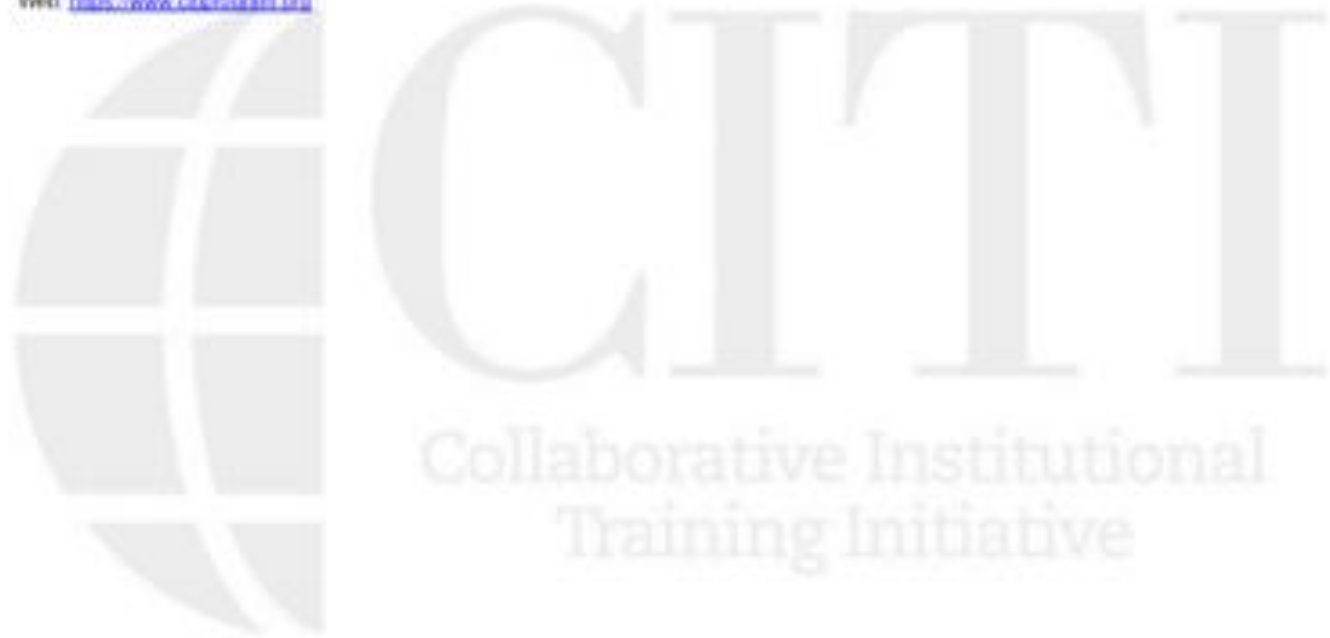